Georgetown University Law Center

Scholarship @ GEORGETOWN LAW

2002

\title{
Venture Capital on the Downside: Preferred Stock and Corporate Control
}

William W. Bratton

Georgetown University Law Center, wwb@law.georgetown.edu

Reprinted from Michigan Law Review, March 2002, Vol. 100, No. 5. Copyright 2002 by William W. Bratton.

This paper can be downloaded free of charge from:

https://scholarship.law.georgetown.edu/facpub/51

100 Mich. L. Rev. 891-945 (2002)

This open-access article is brought to you by the Georgetown Law Library. Posted with permission of the author. Follow this and additional works at: https://scholarship.law.georgetown.edu/facpub

Part of the Business Organizations Law Commons 


\title{
GEORGETOWN LAW Faculty Publications
}

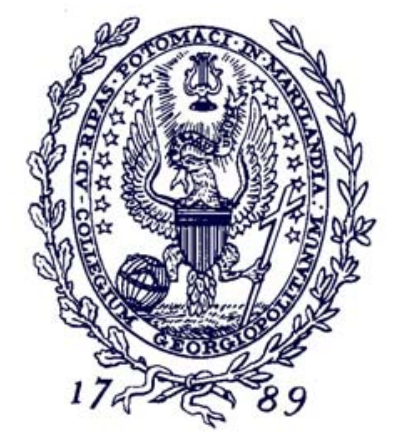

January 2010

\section{Venture Capital on the Downside: Preferred Stock and Corporate Control*}

100 Mich. L. Rev. 891-945 (2002)

\author{
William Wilson Bratton \\ Professor of Law \\ Georgetown University Law Center \\ wwb@law.georgetown.edu
}

This paper can be downloaded without charge from:

Scholarly Commons: http://scholarship.law.georgetown.edu/facpub/51/

SSRN: http:// ssrn.com/abstract $=291588$

Posted with permission of the author

* Reprinted from Michigan Law Review, March 2002, Vol. 100, No. 5. Copyright 2002 by William W. Bratton. 


\title{
VENTURE CAPITAL ON THE DOWNSIDE: PREFERRED STOCK AND CORPORATE CONTROL
}

\author{
William W. Bratton*
}

\section{INTRODUCTION}

When stock indices drop precipitously, when the startup companies fizzle out, and when it stops raining money on places like Wall Street and Silicon Valley, attention turns to downside contracting. Law and business lawyers, sitting in the back seat as mere facilitators on the upside, move up to the front and sometimes even take the wheel. The job is the same on both the upside and downside: to maximize the value of going concern assets. But what comes easily on the upside can be dirty work on the down, where assets need to be separated from dysfunctional teams of business people to stem the flow of red ink to disappointed investors. The team members rarely go quietly, no matter how unsuccessful. The outcome can turn on provisions in contracts entered into on the upside - cookie-cutter paragraphs in boilerplate forms, barely noticed when the cash flows easily.

This Article takes the occasion of the simultaneous collapse of the high technology stock market and the failure of the dot-com startups, ${ }^{1}$ along with the subsequent retrenchment of the venture capital business, ${ }^{2}$ to examine the law and economics of downside arrangements in venture capital contracts. The subject matter implicates core concerns of legal and economic theory of the firm. Debates about the separation of ownership and control, ${ }^{3}$ relational

* Samuel Tyler Research Professor of Law, The George Washington University Law School; Visiting Professor of Law, Georgetown University Law Center. A.B. 1973, Columbia; J.D. 1976, Columbia. - Ed. My thanks to John Armour, Mitu Gulati, William Klein, Joe McCahery, Larry Mitchell, Per Strömberg, and participants at the TIAS Business School conference on e-business for comments on previous versions.

1. In the first seven months of 2001,367 internet companies went out of business, and nearly 83,000 dot-com employees were laid off. One result was a marked uptick in applications to business school. Big Ex-Techies On Campus, BUS. WK., Aug. 13, 2001, at 8 .

2. See Mark Heinzl, Starting Gate, WALL ST. J., July 16, 2001, at B5 (reporting that U.S. venture capital investments in the first quarter of 2001 were $\$ 11.7$ billion compared to $\$ 26.7$ billion in the first quarter of 2000 ).

3. See, e.g., Michael C. Jensen, The Modern Industrial Revolution, Exit, and the Failure of Internal Control Systems, 48 J. FIN. 831 (1993) (arguing that internal governance systems 
investing, ${ }^{4}$ takeover policy, the law and economics of debt capitalization, ${ }^{5}$ and bankruptcy reform, ${ }^{6}$ all grapple with the downside problem of controlling and terminating unsuccessful managers for the benefit of outside debt and equity investors (and the related upside problem of incentivizing effective but fallible managers). The factors motivating these debates also bear on venture capital contracting. But venture capital presents a special puzzle for solution. Convertible preferred stock is the dominant financial contract in the venture capital market, ${ }^{7}$ at least in the United States. ${ }^{8}$ This contrasts with other contexts in corporate finance, where preferred stock is thought to be a financing vehicle long in decline. The only mature firms that finance with preferred, which once was ubiquitous in American capital structures, tend to be firms in regulated industries having little choice in the matter. Tax rules favoring debt finance provide the primary explanation for preferred's decline. But many corporate law observers would suggest dysfunctional downside contracting as a concomitant cause. Simply, preferred performs badly on the downside, where senior security contracts supposedly are at their most effective. Preferred stockholders routinely have been victimized in distress situations by opportunistic issuers who strip them of their contract rights, transferring value to the junior equityholders who control the

are failing at the task of achieving the downsizing and disinvestment needed by the wider economy).

4. See, e.g., Michael E. Porter, Capital Choices: Changing the Way America Invests in Industry, in STUdiES IN INTERNATIONAL CORPORATE FINANCE AND GOVERNANCE SYSTEMS: A COMPARISON OF THE U.S., JAPAN, AND EuROPE 5-17 (Donald H. Chew ed., 1997) (arguing for business and law reform toward the end of encouraging relational investing).

5. See, e.g., Michael C. Jensen, Agency Costs of Free Cash Flow, Corporate Finance and Takeovers, 76 AM. ECON. REV. PAPERS \& PROC. 323 (1986) (arguing that managers put excess cash into suboptimal projects and need to be disciplined by high leverage and takeovers).

6. See, e.g., ThOMAS H. JACKSON, The Logic AND Limits OF BANKRUPTCY 209-24 (1986) (arguing that bankrupt firms should be put up for sale as going concerns rather than recapitalized).

7. See, e.g., William A. Sahlman, The Structure and Governance of Venture-Capital Organizations, 27 J. FIN. ECON. 473 (1990); Jeffrey J. Trester, Venture Capital Contracting Under Asymmetric Information, 22 J. BANKING \& FIN. 675 (1998).

8. Douglas J. Cumming, The Convertible Preferred Equity Puzzle in Canadian Venture Capital Finance (SSRN Elec. Paper Coll. No. 218352, 2001), at $\mathrm{http}: / /$ papers.ssrn.com/abstract=218352, reports that preferred is not extensively utilized in Canadian venture capital financing. This is even true with respect to U.S. venture capital firms' investments in Canada. Douglas Cumming, United States Venture Capital Financial Contracting: Evidence from Investments in Foreign Securities (SSRN Elec. Paper Coll. No. 288111, 2002), at http://papers.ssrn.com/abstract=288111. D. Gordon Smith \& Annaleena Parhankagas, Conflict Management in the Entrepreneur-Venture Capitalist Relationship: An International Comparative Study (working paper on file with author, June 2000) makes the same report for Finland. 
firm's management. The cumulation of bad experiences adds impetus to a wider trend in favor of debt as the mode of senior participation.

Venture capital finance is the exception to the trend. With preferred stock as the investing vehicle of choice, the number of venture capital funds increased from thirty-four with capital of $\$ 1.69$ billion in 1991 to 228 funds with committed capital of $\$ 67.7$ billion in the peak year of $2000 .^{9}$ Given preferred stock's history of contract failure, two questions arise. First, why do American venture capitalists employ preferred instead of debt or common stock, and second, how, if at all, do venture capital preferred contracts solve or avoid downside failure? This Article draws on the economics of incomplete contracts to offer answers to these questions.

The first line of downside defense for any outside source of capital is not closing in the first place. Venture capital contracts employ this defense to the utmost, staging the drawdowns of funds over time and conditioning the funding commitment on performance targets. If the stock issuer misses its target, the venture capitalist has the option of refusing further funds. The venture capitalist's final line of downside defense lies in its preferred stock redemption rights and liquidation preference. Venture capital investments tend to have an intermediate duration. If after five years or so the stock issuer has not produced a payoff in the form of an initial public offering, the venture capitalist has the backstop right to have its stock redeemed at the purchase price. That right implies a power to terminate an issuer unable to fund the redemption, along with priority rights respecting remaining assets.

Between these two lines of defense there lies a middle ground where downside protection may also be needed. This is the ground taken up in this Article. Here downside protection for a venture capitalist means two things - first, power to replace the firm's managers (or, alternatively, to force premature sale or liquidation of the firm), and second, power to protect the venture contract itself from opportunistic amendment. Venture capital investments possess this protection in varying degrees, depending on the mode of their participation and the governing contracts' terms. At the best-protected end of the range of possibilities lie transactions where the venture capitalist holds a majority of the voting shares, whether common or preferred. This imports control of the board and all necessary power to effect results in the firm. Thus situated, a holder of venture capital preferred can block any opportunistic stripping of its priorities and need not overly concern itself with the completeness of the protections

9. Paul Gompers \& Josh Lerner, The Venture Capital Revolution, 15 J. ECON. PERSP. 145, 151, tbl.1 \& n.a. (2001). For a concise overview of all aspects of venture capital contracting, see Michael Klausner \& Kate Litvak, What Economists Have Taught Us About Venture Capital Contracting (SSRN Elec. Paper Coll. No. 280024, 2001), at http://papers.ssrn.com/abstract=280024. 
specified in its contracts. At the opposite, least-protected end of the range of possibilities lie transactions where the venture capitalist holds preferred in the absence of either a voting stock majority or control of the board of directors. With no control whatsoever, the venture capitalist has the burden of extracting protection in the form of express terms of the type conventional in contracts governing senior securities - promises to pay, negative covenants, liquidation provisions, conditions on commitments to make additional investments, and so forth. In many cases these provide a cumbersome, unreliable means to achieve the fundamental downside objective of removing managers or forcing a sale. To see why, consider the archetypical case of a payment default on a bond contract. This is a governance event because as a practical matter it forces a bankruptcy reorganization. But Chapter 11 is designed in the first instance to prevent the removal of managers and to avert a sale of the business. The proceeding will be controlled initially by the incumbent management, which will be biased toward the status quo and will lack a strong commitment toward protecting the contract rights of senior securityholders. ${ }^{10}$

Until recently, academic observers assumed that venture capitalists always insist on full protection, taking voting control of their portfolio companies' shares and dominating their boardrooms. ${ }^{11}$ New empirical work shows that venture capitalists emerge with such full control at both the shareholder and board level in only a significant minority of cases. ${ }^{12}$ In another significant minority of cases, the venture capitalist emerges at the vulnerable end of the range of protection, lacking voting and boardroom control and relying entirely on terms articulated ex ante in the preferred stock contract. In these cases, a risk of exposure to issuer opportunism arises.

This Article evaluates this risk, reviewing contract terms employed in venture capital transactions and the case law on preferred stock. A mixed picture emerges. The terms of venture capital contracts improve in significant respects on those of traditional preferred stock contracts. But they are not perfect, and they offer incomplete protection from issuer opportunism. Meanwhile, the case law is as hostile as ever. Delaware has taken the lead, sustaining a classic case of preferred stock victimization in a venture capital context. This

10. Under section 1121(c) of the Bankruptcy Code, the debtor in possession has the exclusive right to propose a plan during the first 120 days of a proceeding. Section 1129(a), (b) contemplates that seniors can be asked to give up value to juniors subject to the limit that seniors must at least receive liquidation value. 11 U.S.C. $\$ \S 1121$ (c), 1129(a), (b) (1994).

11. See infra text accompanying notes 17-20.

12. Steven Kaplan \& Per Strömberg, Financial Contracting Theory Meets the Real World: An Empirical Analysis of Venture Capital Contracts, (SSRN Elec. Paper Coll. No. 218175, 2000), at http://papers.ssrn.com/abstract=218175. 
Article criticizes this approach as a matter of both contract law and contract economics: contract law's good faith duty can be used to protect venture capital preferred without a cognizable risk of unproductive judicial interference in corporate affairs. The discussion also suggests that Delaware's adherence to the traditional patterns of treatment of preferred is short sighted. Venture capital contracts present a unique alignment of financial and governance interests. A responsive legal regime seeking venture capital incorporations will tailor its contract and fiduciary principles accordingly, developing an even-handed framework in which to arbitrate disputes.

Venture Capital Contracts - The Control Range

\begin{tabular}{|l|l|l|l||}
\hline & $\begin{array}{l}\text { Traditional } \\
\text { Contracts }\end{array}$ & Shared Control & $\begin{array}{l}\text { Full Voting } \\
\text { Control }\end{array}$ \\
\hline $\begin{array}{l}\text { Power to } \\
\text { Control Assets }\end{array}$ & Weak & $\begin{array}{l}\text { Incomplete } \\
\text { Contracting }\end{array}$ & Full \\
\hline $\begin{array}{l}\text { Exposure to } \\
\text { Contract } \\
\text { Opportunism }\end{array}$ & Yes & $\begin{array}{l}\text { No (stock majority) } \\
\text { Yes (stock minority) }\end{array}$ & No \\
\hline
\end{tabular}

The most likely venture capital transaction structure entails neither full protection nor classic preferred stock vulnerability. In the majority of transactions, the venture capitalist emerges at a midpoint on the protection range, sharing control with the entrepreneur. Here the defining characteristic is an open-ended balance of power in the boardroom. The venture capitalist accordingly gets no unilateral power to control the assets and terminate the entrepreneur on the downside. Instead these matters are left open to contest. In a majority of this subset of transactions, the venture capitalist takes a majority of the voting stock even though it does not take a majority of board seats. The stock majority imports determinative protection against the stripping of contract rights. In a significant minority of these sharedcontrol transactions, however, the entrepreneur holds a minority of the shares with control in the boardroom being shared. This arrangement opens up a possibility of exposure to opportunism respecting the preferred stock contract.

In sum, in a majority of venture capital transactions, the venture capitalist takes a cognizable risk of not getting the results it wants on 
the downside. This Article addresses the question of why this occurs using a model of optimal capital structure in startup investment contexts drawn from the economic literature of incomplete contracts. The model, which abstracts from the leading description of control transfer between entrepreneurs and outside capitalists proposed by Phillippe Aghion and Patrick Bolton, ${ }^{13}$ lets us explain the pattern of venture capital contracting in terms of the rational provision of production incentives. ${ }^{14}$ More particularly, shared control arrangements are governance processes that avert problems of noncontractibility. When parties enter into venture capital contracts they are in a position to legislate respecting some but not all future outcomes. Fabulous success, for example, presents allocational problems but no questions respecting the entrepreneur's control of the assets in the future. Total failure is similarly cut and dried - the contracts trigger liquidation for the benefit of the venture capitalist subject to the constraints of the bankruptcy system. Middling outcomes are less amenable to advance specification. Here, control transfers implicate complex business judgments outside the scope of existing contract technologies. Such scenarios are better suited to treatment through the operation of a contractually instituted governance processes than through advance specification of a clearcut outcome. Venture capital's shared control arrangements achieve this end, making the entrepreneur's day-to-day control of assets and management contestable and facilitating control transfer at low cost even while giving the entrepreneur some assurance that control transfer power will not be arbitrarily exercised.

Part I begins by setting out recent empirical findings on venture capital contracts. Next, Part I articulates the terms of the control allocation model of optimal capital structure of Aghion and Bolton. Part I then brings the real world contracting pattern to the model and the model to the real world pattern. ${ }^{15}$ This encounter expands the model's framework, yielding a menu of contract specifications and governance processes from which parties to venture capital contracts

13. Philippe Aghion \& Patrick Bolton, An Incomplete Contracts Approach to Financial Contracting, 59 REV. ECON. STUD. 473 (1992). In so doing, it follows the suggestion of Kaplan \& Strömberg, supra note 12, that the Aghion-Bolton model is the most cogent of the theoretical explications of venture capital relationships. Thomas Hellmann, The Allocation of Control Rights in Venture Capital Contracts, 29 RAND J. ECON. 57 (1998), makes the same commendation.

14. The fit between the Aghion-Bolton construct and the real world contracting pattern is not precise. In order to explain the ambiguous, shared control arrangements that dominate venture capital contracting, the model's menu of modes of control transfer and decisionmaking contingencies has to be expanded. This Article fills in the additional menu items.

15. For another discussion of the Aghion-Bolton model and the Kaplan and Strömberg results, see Oliver Hart, Financial Contracting, 39 J. ECON. LIT. 1079, 1084-90 (2001). 
can select. We emerge with a thick but workable description of control relationships between venture capitalists and entrepreneurs.

Part II turns to the legal environment and contracting practice respecting the preferred stock. It begins by showing the ease with which opportunistic managers have historically diverted value from preferred holders. The discussion then turns to venture capital preferred, showing how history repeated itself in the Delaware courts in the leading case concerning the rights of venture capital preferred, Equity-Linked Investors, L.P. v. Adams. ${ }^{16}$ Finally, Part II returns to real world venture capital contracting practice and the strategies it employs to reverse the historical pattern of preferred exposure. The verdict is one of qualified success.

The qualification is important, given a venture capitalist averse to contract risk. This Article's analysis implies conservative advice: invulnerability to issuer opportunism presupposes voting control of the stock and, at a minimum, shared control in the boardroom. In the present legal context, contract protections without control remain unreliable. This advice is hardly satisfactory as a policy matter. Accordingly, the Article concludes that the legal framework encasing preferred stock has not evolved in an efficient direction.

\section{Control in Venture Capital Investment: From Practice TO THEORY}

This Part gathers, evaluates, and restates the economic learning on venture capital contracts. Section A sets out recently reported data on business practices respecting venture capital contracts. The data displace a longstanding assumption that venture capitalists always take complete voting control of their portfolio companies. Section B describes incomplete contracts economics and explains its appropriateness as a framework of inquiry respecting capital structure. Section $\mathrm{C}$ sets out a basic incomplete contracts model of a control transfer capital structure (the Control Transfer Model, or CTM), abstracting from research by the economists Philippe Aghion and Patrick Bolton. Section D expands the model's analytical framework so as to provide a working account of real world venture capital governance structures.

\section{A. Contracts and Control Arrangements in Venture Capital Finance}

In the once-prevailing story about venture capital transactions, entrepreneurs so need venture capital that they cede both a majority of stock and control of the boardroom. The control transfer to the venture capitalist $(V C)$ is only temporary, however. If the portfolio

16. 705 A.2d 1040 (Del. Ch. 1997). 
company succeeds, control returns to the entrepreneur $(E)$ when $V C$ sells its stock in an initial public offering ("IPO"). ${ }^{17}$ Thus, in Ronald Gilson and Bernard Black's description, the problem for solution with venture capital contracts is $E$ 's lack of assurance against opportunistic retention of control by $V C$ through undue delay of the IPO. They suggest that an "implicit contract" backed by reputational constraints and financial incentives assures $E$ that $V C$ will voluntarily surrender the reins. ${ }^{18}$ Note that so long as $V C$ has control, its senior status is completely protected. Indeed, according to Gilson and Black, the practice in venture capital transactions gives $V C$ double protection, investing it with veto power over business decisions through a full set of business covenants. ${ }^{19}$

The $V C$ control story, however, has turned out to be incomplete. ${ }^{20}$ The reversal is understandable. Venture capital transactions are private placements. There is accordingly no public database respecting their financial terms and contracting structures. Actors in the industry, moreover, can be expected to take a proprietary view respecting their transactions' documentation. The economists Kaplan and Strömberg have broken new ground just by gathering data respecting the contracts governing venture capital investments in 118 startups (200 separate instances of investment) made by fourteen venture capital firms located across the country. The data displace the standard story, showing that $V C$ s do not always take control of their portfolio firms. ${ }^{21}$ The theory of the firm has a lot of explaining to do as a result.

17. Bernard S. Black \& Ronald J. Gilson, Venture Capital and the Structure of Capital Markets: Banks Versus Stock Markets, 47 J. FIN. ECON. 243, 253, 255-56, 260-61 (1998).

18. Id. at 257-64.

19. Id. at 261 .

20. It also should be noted that the IPO is not the only means of $V C$ exit on the upside. Four additional routes are available: (1) the $V C$ can retain all or part of its shares and sell them into the trading market subsequent to the IPO; (2) the firm can be sold to a third-party acquirer, with the $V C$ taking a share of merger consideration upon exit; (3) the $V C$ can sell its shares to a third-party acquirer; and (4) the $V C$ can sell its shares back to the issuer or to $E$. Any of these exits can be partial or full. For discussion of possibilities and practices, including empirical results in the U.S. and Canada, see Douglas J. Cumming \& Jeffrey G. MacIntosh, The Extent of Venture Capital Exits: Evidence from Canada and the United States (SSRN Elec. Paper Coll. No. 250519, 2000), at http://papers.ssrn.com/abstract=250519. Cumming and MacIntosh suggest that the likelihood of exit increases over time; the value added by the VC declines as the firm matures, management becomes more seasoned, the firm's business contacts are put in place, and product development and marketing issues are resolved. D. Gordon Smith, Control Over Exit in Venture Capital Relationships (SSRN Elec. Paper Coll. No. 272231, 2001), at http://papers.ssrn.com/abstract=272231), studies the regulation of exit in venture capital contracts, showing that the $V C$ comes to acquire control over exit over time.

21. Significantly, the touchstone discussion of venture capital contracting, Sahlman, supra note 7 , at 506 , makes no assertion respecting the frequency of $V C$ control. It does note the incidence of shared control in the boardroom. 
Kaplan and Strömberg find that one or the other party, $V C$ or $E$, has control of the board in only $38 \%$ of their cases. In this subset, the $V C$ takes control in two-thirds of the cases and the $E$ takes control in one-third of the cases. Also, cases of $V C$ control are more likely to occur in late stage financings. In the remaining $62 \%$ of the cases, neither side takes control. ${ }^{22}$ Instead, the $V C$ and the $E$ each designate a director for a seat or seats. They then agree on a candidate to fill the remaining seat or seats. Under standard corporate law on allocation of authority, control of the boardroom means control of the assets and personnel. ${ }^{23}$ The upshot on the downside, assuming conflicting views in $E$ and $V C$ as to the best course of action, or, indeed, assuming that $V C$ wishes to remove $E$ from the position of chief executive officer ("CEO"), is that the views and votes of the third director are outcome determinative.

Kaplan and Strömberg also collect data on voting control at the shareholder level. At this point recall that while a majority of the voting shares means boardroom control with plain vanilla corporate documentation, standard corporate practice permits shareholders to make special contractual arrangements respecting boardroom control. Such is the case with venture capital transactions, which tend to provide separate voting schemes for board election, on the one hand, and for other matters on which shareholders vote, on the other hand. The latter proceed on a one vote-per-share basis. ${ }^{24}$ Accordingly, voting control over matters like charter amendments and mergers goes to the actor, $E$ or $V C$, holding the largest number of shares. The number of and proportion of shares held by $E$ and $V C$ in turn will vary depending on how well $E$ performs. It is customary in venture capital contracting to use stock ownership as a performance incentive for $E$, setting out performance targets and providing that more stock vests in $E$ as the targets are met. Kaplan and Strömberg report that in $70.8 \%$ of cases, the $V C$ controls a majority of the votes, assuming no performancebased stock allocations to the $E$ ever come to vest. Given full vesting, the number of cases in which $V C$ controls a majority decreases to $55.8 \%$. $E$ controls in $11.6 \%$ of the cases, rising to $23.1 \%$ given full vesting. Neither party controls in $17.6 \%$, rising to $21.1 \%$ given full vesting. Some variance comes into the figures in subsets broken down by round of investment. $V C$ control is higher $(86.8 \%$, no vesting; $65.8 \%$ full vesting) in rounds conducted where the startup has not yet produced revenues and lower in post revenue rounds $(59.0 \%$ no vesting; $48.7 \%$ full vesting). The net on the downside, where full

22. Kaplan \& Strömberg, supra note 12 (working paper at 17 ).

23. See, e.g., DEL. CodE ANN. tit. $8, \S 141$ (a) (2001).

24. Or, in the case of the $V C$, a vote equal to the number of shares of common stock into which its shares are convertible. 
vesting of $E$ performance-based stock is unlikely to have occurred, strongly favors $V C$ voting control.

\section{Venture Capital Contracts - The Control Range KAPLAN \& STRÖMBERG'S RESULTS}

\begin{tabular}{|c|c|c|c|}
\hline & $\begin{array}{c}\text { Traditional } \\
\text { Contracts - } \\
E \text { Voting } \\
\text { Control }\end{array}$ & $\begin{array}{l}\text { Shared } \\
\text { Control }\end{array}$ & $\begin{array}{l}\text { Voting } \\
\text { Control in } \\
V C\end{array}$ \\
\hline $\begin{array}{l}\text { Power to Control Assets / } \\
\text { Control of Board of } \\
\text { Directors }\end{array}$ & $13 \%$ & $62 \%$ & $25 \%$ \\
\hline $\begin{array}{l}\text { Exposure to Contract } \\
\text { Opportunism } \\
\text { Majority of Voting Shares } \\
\text { No Vesting } \\
\text { Full Vesting }\end{array}$ & $\begin{array}{l}11.6 \% \\
23.1 \%\end{array}$ & $\begin{array}{l}17.6 \% \\
21.1 \%\end{array}$ & $\begin{array}{l}70.8 \% \\
55.8 \%\end{array}$ \\
\hline
\end{tabular}

Kaplan and Strömberg show strong correlations between share voting control and board control. Where $V C$ has voting control, $V C$ also has board control in $22.5 \%$ of the cases, but board control is shared in $70 \%$ of the cases where $V C$ has voting control. Where $V C$ never has voting control, board control is shared in $58.1 \%$ of the cases; $E$ controls in $38.7 \%$ of the cases. Where $V C$ has voting control subject to divestment given $E$ equity vesting, board control is shared in $94.1 \%$ of the cases. A correlation between voting rights and cash flow rights also can be noted. The $V C$ mean economic ownership claim in all transactions assuming no vesting is $55.7 \%$ and $47.6 \%$ with full vesting.

Finally, Kaplan and Strömberg report that in $15 \%$ of the cases, the documentation defines a state of unacceptable suboptimal performance in advance by reference to financial information and provides for a state-contingent transfer of control to the venture capitalist. ${ }^{25}$

Summing up, shared control in the boardroom is the dominant governance mode in the portfolio companies in Kaplan and

25. Kaplan \& Strömberg, supra note 12 (working paper at 59 tbl. 6, 60 tbl. 7). 
Strömberg's sample. It even prevails in a majority of the cases where one or the other of $V C$ or $E$ has a majority of voting shares. But, at the same time, $V C$ and $E$ each have boardroom control in significant numbers of portfolio companies. This data complicates the explanatory task for theory of the firm. The question is neither why $V C$ control, nor why $E$ control. It is, first, why shared control in most cases with outlier cases of $V C$ control and $E$ control? Second, how, if at all, do the shared control arrangements described in Kaplan and Strömberg's sample function so as to assure full realization of a given startup's profit potential?

\section{B. Incomplete Contracts Theories of the Firm}

This Article's principal assertion is that the value of shared control lies in the fact that it makes E's day-to-day control of assets and management contestable, facilitating control transfer at low cost even as it gives $E$ a degree of assurance against arbitrary and capricious exercise of that control transfer power. To see why these factors are important, look at the situation ex ante, before $V C$ commits its money. $V C$ knows that $E$ could have a valuable business idea even while simultaneously turning out to be a poor manager. $E$ knows that $V C$ s bring this skeptical point of view to their review of portfolio companies, but $E$ also knows that $V C$ s are not immune to adverse selection and may not be infallible in their business judgments. Both parties also know that as events unfold, $E$ and $V C$ may interpret them differently, with $E$ as the inside party having an advantage respecting hard information. There results a nascent conflict of interest, which may or may not ripen depending on future events. A shared control arrangement holds out advantages as a solution. It gives $V C$ a governance structure that contemplates ex ante that a professional manager may have to replace $E$. At the same time, shared control lets $E$ take charge of the business without being $V C$ 's at-will employee, as would be the case if $V C$ had control of the board. The shared-control arrangement leaves the matter of $E$ 's performance evaluation open and waits for events to unfold.

$V C$ will want to take control of the assets and replace $E$ on a moderate downside scenario ${ }^{26}$ - the portfolio company still has prospects but $E$ does not appear to be equipped to realize them. Such mediocre or poor performance can stem from adverse selection or moral hazard problems. In either case, it would not give rise to conflict of interest and contracting problems between $E$ and $V C$ in a world

26. A catastrophic downside scenario arises when the portfolio company's business has no prospects under anyone's management. Here $V C$ contracts in the end provide for termination with the $V C$ taking the crumbs off the table. See infra text accompanying note 149. 
where $E$ derives no private benefits from the control of assets. Oliver Hart shows that in such an ideal (and taxless) world, first-best results easily can be achieved with an all-common-stock capital structure and a simple incentive compensation system. Hart describes a simple twoperiod situation where the firm is founded at $t=0$ and liquidated at $t=$ 2 , with an intermediate decision respecting liquidation or continuance to be made at $t=1$, along with a dividend payment. Hart would make the compensation of the managing participant $E$ depend entirely on the dividend $d$. That is, incentive compensation $I$ should equal " $P(d 1+$ $d 2$ ), "where $P$ is a proportion of the firm's total returns. If the payment also covers a proportion of liquidation proceeds $L-I=$ $P[d 1+(d 2, L)]-E$ can be expected to make an optimal decision respecting liquidation at $t=1$. If the expected value of liquidation returns at $t=1$ is greater than the total returns expected at $t=2$, the firm is liquidated at $t=1$ and no costly contracting designed to align the manager's incentives with those of outside investors is necessary. ${ }^{27}$ Under this incentive structure there is no ex ante prospect of firm continuance in the event of poor results.

The real world problem is that managers like $E$ do derive private benefits from asset management. In Hart's conception, the bribe required to align their incentives with those of the outside security holders is unfeasibly large. ${ }^{28}$ Accordingly, a complex capital structure must be devised in order to align incentives in the direction of optimal investment and management and to ensure that the actor with the appropriate incentives controls the assets.

Incomplete contracts models of capital structure seek to describe such incentive-compatible capital structures. They start with a common sense definition of contracts: contracts are comprised of advance specifications of future results. To the extent that a given outcome cannot successfully be specified in advance, the subject matter is noncontractible. The models make three assertions about corporate contracts and capital structures. First, corporate contracts can be expected to omit important future variables because of the difficulty or impossibility of ex ante description. That is, the particular posture of events on which critical governance outcomes will later depend may not be sufficiently specifiable in advance so as to permit the parties to draft in advance a contract term setting out appropriate instructions. Second, corporate contracts can be expected to omit

27. Oliver Hart, Firms, Contracts, AND Financial STRucture 146-48 (1995); see also Anat R. Admati \& Paul Pfleiderer, Robust Financial Contracting and the Role of Venture Capitalists, 49 J. FIN. 371 (1994) (setting forth the fixed fraction model of venture capitalist participation).

28. See HAR', supra note 27 , at $146-48$. The treatment of Hellmann, supra note 13 , should be contrasted at this point. In that set up, $E$ 's private benefits from control may be outweighed by the upside prospects of a payoff on $E$ 's common stock in the firm, which payoff will be realized only if $E$ gives up control. 
important future variables due to the difficulty or impossibility of ex post observation and verification. ${ }^{29}$ That is, even if the parties can anticipate and describe future contingencies, once events have unfolded in the future, no concrete factual basis may exist for the operation of an advance legislative directive. To enforce a contractual specification, you must be able to make a proof in court. Complex facts of business life do not always lend themselves to such presentations, especially by those outside the firm, whether government regulators or $V C s$. Meanwhile, hard accounting numbers produced by a firm do not by themselves direct business judgments and are in any event subject to manipulation by insiders. And noncontractibility may obtain because the requisite transactional technologies do not yet exist. ${ }^{30}$ Third, given the foregoing problems of noncontractibility, important outcomes in corporate contracts will be determined not by advance specification but by the firm's structure of ownership. The specification of the owner and any associated contingent control allocations built into the firm's contracts - in particular the contracts making up the capital structure - substitute for contract terms absent due to the condition of contractual incompleteness. ${ }^{31}$

As the zone of noncontractible contingencies expands, the ownership specifications become more important. Ownership and control of the assets will not be vested in perpetuity in a single actor, because doing so would both imply a low-powered performance incentive and leave the firm without defense against adverse selection and opportunism. In this conceptualization, the firm's present owners are the actors who direct its ongoing management and investment policies, or, in the alternative, who determine whether to sell or

29. For contributions to the literature making this point, see Sanford J. Grossman \& Oliver D. Hart, The Costs and Benefits of Ownership: A Theory of Vertical and Lateral Integration, 94 J. POL. ECON. 691 (1986); Oliver Hart \& John Moore, Incomplete Contracts and Renegotiation, 56 ECONOMETRICA 755 (1988) [hereinafter Hart \& Moore, Incomplete Contracts]; Bengt Holmstrom \& Paul Milgrom, Multitask Principal-Agent Analyses: Incentive Contracts, Asset Ownership, and Job Design, 7 J.L. ECON. \& ORG. 24 (1991) (special issue) (showing that contracts that tie an agent's compensation to verifiable measures can divert effort and attention from other more important but less easily measured aspects of performance).

30. Unlike most law and economics, which tends to include any voluntary economic relation within its notion of the ex ante contract, incomplete contracts theory restricts the reach of the ex ante contract to cases where actors make explicit specifications about the future. That is, to have "contract" terms that govern future states, those contingent states must be specified and the future outcomes must be computable. Since many future states of nature clearly are not computable, transacting parties as a result lack the technology necessary to enable the negotiation and composition of a contract term ex ante. See Luca Anderlini \& Leonardo Felli, Incomplete Written Contracts: Undescribable States of Nature, 109 Q.J. ECON. 1085 (1994).

31. See Aghion \& Bolton, supra note 13, at 479. 
liquidate the firm. ${ }^{32}$ In the event of suboptimal performance, control transfer to an actor possessing more compatible incentives may be advisable. The firm's performance thus depends on the incentives not only of its present owners but of its contingent future owners. Optimal capital structure depends on the control transfer arrangements that shape these incentives. ${ }^{33}$

Significantly, incomplete contracts economics makes no resort to "implicit contracts" as it describes governance structures. The term implicit contracts, as used in law and economics, describes counterparty conduct that a given contract party expects (often in a situation of trust or reliance), but as to which no explicit requirement exists in the contract. Such expectations often arise respecting future events as to which contractual specification satisfying all parties is difficult or impossible. Implicit contracts fill these gaps. But they do not do so as implied, legally enforceable duties, as do the implied contracts of contract law. In the law and economics usage, no legal constraints follow from the identification of an implicit contract. More often than not, the dependent party is left exposed to counterparty opportunism and remitted to self-protection through explicit contracting the next time around. In giving this instruction, the implicit contracts approach makes a significant assumption - that the zone of contractibility is universal and that incomplete contracts always can be completed. Given that assumption, it appears to make good policy sense to deploy the law so as to force the parties to conclude their own contracts rather than insert contract terms devised by judges acting ex post. ${ }^{34}$

Incomplete contracts economics holds out a distinctly different approach to contracts because it does not assume universal

32. Notably, "owner" is here specially defined as the party who has the right to control all aspects of the asset that have not been given over to contractual specification ex ante. Grossman \& Hart, supra note 29, at 695. Under this definition, ownership and control cannot be separated, although they can be shared. Since asset control is ownership, residual claimants who do not manage are not owners, whatever the law's contemplation.

33. It should be noted that the basic assertions of the incomplete contracts school are a subject of debate in economic theory. See Eric Maskin \& Jean Tirole, Unforeseen Contingencies and Incomplete Contracts, 66 REV. ECON. STUD. 83 (1999), for an argument that parties can indeed design contracts that overcome the problems the school describes as "noncontractible," and that irrelevance obtains as between an incomplete contract left open to ex post renegotiation and a contract with described trades. The response appears in Oliver Hart \& John Moore, Foundations of Incomplete Contracts, 66 REV. ECON. STUD. 115 (1999) [hereinafter Hart \& Moore, Foundations].

34. See Frank H. Easterbrook \& Daniel R. Fischel, Contract and Fiduciary Duty, 36 J.L. \& ECON. 425, 445 (1993) (asserting a presumption in favor of forcing parties to get their own contracts). At the same time, gaps can be filled in when the decisionmaker knows what the actors would have agreed on in a costless contracting environment. See, e.g., Jeffrey N. Gordon, The Mandatory Structure of Corporate Law, 89 COLUM. L. REV, 1549, 1550-52 (1989). To the author's knowledge, the latter principle has never been brought to bear to protect a senior securityholder. 
contractibility. Indeed, it holds that transacting actors can create producing institutions that assuredly evolve toward the first-best only to the extent that they deal with contractible subject matter. Absent contractibility, we necessarily are in a second-best world, where the function of economics is to identify and explain barriers that prevent the evolution of first-best transaction structures. In this second-best world, no all-pervasive presumption against regulation arises. Where subject matter is noncontractible, problems have to be sorted out ex post, and it makes no sense to remit parties to ex ante contract. It does not necessarily follow that a given judicial or other regulatory intervention will move actors in a productive direction. In theory, given ideal circumstances, incompleteness only means that the parties themselves renegotiate ex post once the requisite facts are on the table. ${ }^{35}$ In the real world, however, such renegotiations do not necessarily occur under ideal conditions. Determinations about the desirability of judicial intervention to protect against opportunism accordingly have to be made case by case.

\section{The Contingent Control Model}

There follows a contingent control transfer model ("CTM") abstracted from precedent work by Aghion and Bolton so as to appear in an accessible form keyed to the description of real world venture capital arrangements. ${ }^{36}$ The CTM is well suited to the exposition of the control transfer problem in venture capital contexts. ${ }^{37}$ This section recounts its main properties. The section that follows discusses its implications for real world venture capital contracting.

\section{The Setup}

Once again we get a two-period model built on a stylized picture of the relationship between $E$ and $V C$. The two-period framework follows the life of a firm from birth to liquidation, facilitating a dynamic inquiry into the incentive effects of different capital structures. An amount $K$ is invested in the firm at $t=0$; all of $K$ comes from $V C$. The firm is liquidated at $t=2$, when monetary returns $r$ are

35. The dispute between Maskin \& Tirole and Hart \& Moore, see supra note 33, in part turns on whether the parties credibly can commit not to renegotiate. If they can, then the case for investing resources in advance specification strengthens. See Hart \& Moore, Foundations, supra note 33, at 128.

36. See Aghion \& Bolton, supra note 13, at 479. The model is applied in the context of a discussion of dividend policy in William W. Bratton, Dividends, Noncontractibility, and Corporate Law, 19 CARDozo L. REv. 409, 429-34 (1997). For contrasting theoretical pictures of control transfer in senior-junior security holder contexts, see $G$. Mitu Gulati et al., Connected Contracts, 47 UCLA L. REV. 887, 908-18 (1999); D. Gordon Smith, Team Production in Venture Capital Investing, 24 J. CORP. L. 949 (1999).

37. See Kaplan \& Strömberg, supra note 12. 
realized. The amount of the payout will depend on an action $a$ to be taken from among the set of feasible actions $A$ by the actor in control of the firm after the realization of a state of nature $\theta$ at $t=1$. There are only two possible future states of nature, a good business state $\theta_{g}$ and a bad business state $\theta_{b}$. Different actions $a$ will be optimal depending on which state occurs. More particularly, action set $A$ contains only two possible actions, $a_{g}$ and $a_{b}$, in each of the two states of nature $\theta_{g}$ and $\theta_{b}$. In state $\theta_{g}$ the maximizing choice of action $a^{*}$ is $a_{g}$, and in state $\theta_{b}$ the first-best choice of action $a^{*}$ is $a_{b}$. Just which $\theta$ is going to occur is not clear at $t=0$, when $E$ and $V C$ enter into a contract which must address the contingency of respecting the future choice of $a$. At $t=1$, immediately prior to the time for the choice of $a$, the operation of the business will produce a signal $s$ as to the state of nature $\theta_{g}$ or $\theta_{b}{ }^{38}$

\section{CONTINGENT CONTROL MODEL — TIME SEQUENCE}

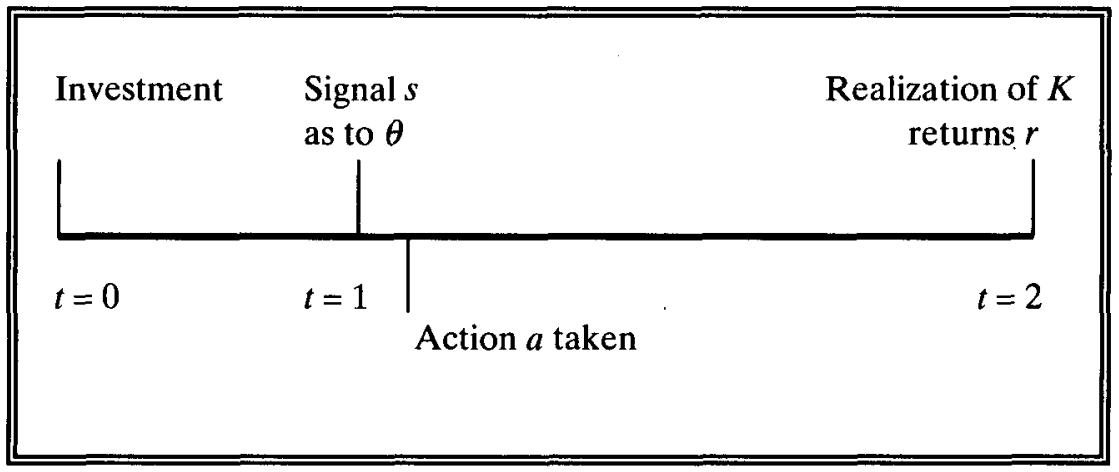

The model works the classic conflict-of-interest problem between $E$ and $V C$ through this framework. The interests come into conflict because returns to $E$ and $V C$ are received in different forms such that choices of different actions a can impact them differentially. ${ }^{39}$ Monetary returns of the project $r$ are payable to $V C$ at $t=2$, minus amounts of compensation payable to $E$ pursuant to a compensation schedule in the contract concluded at $t=0$ by $E$ and $V C$. The compensation arrangement provides a transfer $t \geq 0$, the precise amount of which is a function of $s$ and $r$. Thus $V C$ 's payout $y=r-t$.

38. Aghion \& Bolton, supra note 13 , at $475-78$. The model also assumes that $E$ has no wealth and needs to finance the entire startup cost $K$ for her project. A number of additional assumptions are made. There are only two possible outcomes for $s, 0$ or 1 , with $s=1$ meaning that it is more probable than not that $\theta=\theta_{s}$, and $s=0$ meaning that it is more probable than not that $\theta=\theta_{b}$. In order to make the initial investment of $K$ plausible, the probability $q$ of $y_{8}$ $+(I-q) y_{b}>K$. In addition, there are only two possible returns $r$ at $t=2$, either 0 or 1 , and the initial contract between $E$ and $V C$ may be renegotiated after the realization of $\theta$, with all the bargaining power lying with $E$. Id. at 477-79.

39. The model assumes that both $E$ and $V C$ are risk neutral as to income. $I d$. at 476. 
Critically, $E$ also receives significant, nonmonetary private benefits $b$, such as reputation, which are not also received by $V C$. The quantum of $b$ is a legitimate part of the overall yield of value from the project, but is neither observable nor verifiable by third parties. Yields of both $r$ and $b$ will depend on the state of nature $\theta$ and the choice of $a$. $E$ 's yield is a function of $r(a, \theta)+b(a, \theta)$, and $V C$ 's yield is solely a function of $r(a, \theta)$. The conflict of interest devolves on the choice of $a$ because the choice of $a$ can differentially impact $r$ and $b$, and open up a significant differential of returns between $V C$ and $E .^{40}$

$E$ and $V C$ confront significant problems of noncontractibility at $t=$ 0 . It would be easy if the state of nature $\theta$ could be specified ex ante. Then it might be possible for the contract between $E$ and $V C$ to direct the party in control, presumably $E$, to take a jointly maximizing action $a *$. Unfortunately $\theta$ is impossible or very costly to describe ex ante, although the parties will be able to identify $\theta$ ex post, at $t=2$. The model does, however, assume that even though the $E-V C$ contract cannot be made directly contingent on $\theta$, it can be made contingent on the signal $s$, which is verifiable although imperfectly correlated with $\theta$. Even so, the occurrence of $s$ at $t=1$ does not enable the drafting of a complete contract. Even if $s$ perfectly correlated with $\theta$, the project still would be too complex to permit an ex ante specification of the optimizing response $a_{g}$ or $a_{b}$ upon the realization of $s$. Although the set of choices will be limited to $a_{g}$ and $a_{b}$, the model makes the realistic assumption that both will lie wholly within the realm of traditional management business judgment to be exercised by the actor in control of the firm. Neither is susceptible to direct specification or to indirect specification through a constellation of affirmative and negative covenants. ${ }^{41}$

The upshot is that the capital structure's allocation of control rights between $E$ and $V C$ will determine the choice of $a$ and the level of value, optimal or suboptimal, yielded by the firm. ${ }^{42}$ The capital structure, as set out in the $E-V C$ contract, inevitably specifies an allocation of control which in turn determines which actor has the privilege to chose action $a$. Control can lie in $E$ or in $V C$ or in both.

40. Aghion \& Bolton, supra note 13, at 476. Given the specification of first best action $a_{8}$ and $a_{b}$, the expected returns $y$ and private benefits $b$ realized by $V C$ and $E$ in $\theta_{g}$ and $\theta_{b}$ will have the following properties:

$$
\begin{aligned}
& y \theta_{g} a_{g}+b \theta_{g} a_{g}>y \theta_{g} a_{b}+b \theta_{g} a_{b} \\
& y \theta_{b} a_{b}+b \theta_{b} a_{b}>y \theta_{b} a_{g}+b \theta_{b} a_{g}
\end{aligned}
$$

41. Direct specification might be possible in a different case, where $a_{g}$ and $a_{b}$ entail a selection between a limited set of choices identifiable in advance - for example, either merger, liquidation, or sale of assets. But even given the feasibility of that sort of specification, ex post judicial enforcement of the contractual directive could still fall short of feasibility if information asymmetries led to problems of third-party verification. Aghion \& Bolton, supra note 13 , at $477-78$.

42. Id. at 476-77. 
The CTM works through the scenarios of $E$ control, $V C$ control, and joint control to ascertain the distance between the set of results built in by the incentive structure and first-best set of results: Where $E$ controls, a first-best choice of action follows automatically only when the choice of $a^{*}$ also happens to maximize $y, b$, and the transfer payment $t$. Here $E$ 's incentives are perfectly aligned with the general maximizing result. ${ }^{43}$ But, given the way the CTM is set up, on some outcomes the incentives are misaligned - when $E$ controls, its private benefits cause it to make the wrong choice on a bad outcome. $V C$ 's choice of action is suboptimal on a good outcome.

The CTM runs two modes of working around the misaligned incentives. The first is Coasian bargaining, modeled on the assumption that the entrepreneur has all the bargaining power. ${ }^{44}$ The second is control transfer specified in advance in the $E-V C$ contract and triggered by the signal $s$.

\section{Coasian Bargaining}

It is a truism of law and economics that even given misaligned incentives, an optimal result, here $a^{*}$, can result from a round of Coasian bargaining ex post. Given subject matter presenting contractibility problems, Coasian bargaining is a particularly attractive alternative because it lets the parties leave the matter open ex ante, saving on transaction costs and avoiding use of dysfunctional provisions. In the CTM, a round of negotiation would occur after the realization of $s$ at $t=1$ in which a noncontrolling party benefitted by the choice of $a^{*}$ purchases its choice by the controlling party with a side payment. ${ }^{45}$ Assuming $\theta_{b}$, we speak of a case where $a^{*}=a_{b}$, but the private benefit return $b$ to $E$ yielded by a choice of a suboptimal choice of $a_{g}$ is greater than value of $b$ yielded by the choice of $a^{*}$. In addition, the yield of $y$ to $V C$ is greater if $a^{*}$ is chosen over $a_{g^{*}}{ }^{46}$ For simplicity, the model assumes that $E$ has all the bargaining power. Given the above alignment of values, $E$ will offer to choose $a^{*}$ (here $\left.\theta_{b} a_{b}\right)$ if $V C$ pays $E$ the sum equal to the difference between the value of $y$ yielded on the choice of $a^{*}$ and the value of $y$ yielded on a suboptimal choice of $a .^{47} V C$ can be expected to accept the offer provided that the amount offered is greater than its original

43. Id, at $480-81$.

44. The model assumes that the world is full of venture capitalists but contains only a few entrepreneurs with good projects. $E$ as a result has all the bargaining power: $E$ can make a take-it-or-leave-it offer which $V C$ will accept so long as the deal holds out an expected return of at least $K$. $I d$. at $480-82$.

45. See HART, supra note 27, at 98 (discussing the Aghion-Bolton model).

46. That is, $b\left(\theta_{b} a_{g}\right)+t>b\left(\theta_{b} a_{b}\right)+t$, and $y\left(\theta_{b} a_{b}\right)>y\left(\theta_{b} a_{g}\right)$.

47. That is, $y\left(\theta_{b} a_{b}\right)-y\left(\theta_{b} a_{g}\right)$, provided that $b\left(\theta_{b} a_{b}\right)+t+y\left(\theta_{b} a_{b}\right)-y\left(\theta_{b} a_{g}\right) \geq b\left(\theta_{b} a_{g}\right)+t$. 
investment $K .^{48}$ Assuming $\theta_{g}$, then $a^{*}=a_{g}$, and a round of bargaining results if the private benefit return $b$ to $E$ yielded by a suboptimal choice of $a_{b}$ is greater than the yield of $b$ on a choice of $a^{*}$ and the yield of $y$ to $V C$ is greater where $a^{*}$ is chosen over $a_{b}{ }^{49}$ Since $E$ has all the bargaining power, $E$ will offer to choose $a^{*}$ (here $\theta_{g} a_{g}$ ) if $V C$ pays $E$ the difference between the value of $y$ yielded on the choice of $a^{*}$ and the value of $y$ yielded on a suboptimal choice of $a .^{50}$ Once again, $V C$ can be expected to accept the offer provided that the amount offered is greater than its original investment $K$. Stated differently, on a bad state with $E$ in control, if the increase in returns to $V C$ that results from substituting an optimal choice of action is greater than the differential in returns to $E$ that results from abandoning the suboptimal action, then $V C$, given the signal of a bad outcome, will bribe $E$ with a payment that at least makes up $E$ 's differential so long as the returns to $V C$ net of the payments pay back at least its original investment and make it better off than it would be with the suboptimal choice.

The problem is that, given the CTM's set up, Coasian bargaining does not always lead to an efficient result. This insufficiency stems from the fact that renegotiation leading to $a^{*}$ does not result in every case. The model assumes, realistically enough, that the return of at least $K$ constitutes a rationality constraint for $V C$. Thus, the renegotiation fails and the first-best result will not be chosen if the value of $K$ is so high that it exceeds the yield on offer by $E$. The very possibility that this situation could arise has destabilizing implications for the whole deal: $V C$ can be expected to refuse to invest at $t=0$ unless some form of protection against $E$ 's opportunism is included in the contract package. ${ }^{51}$

In general, Coasian bargaining fails to assure optimal results in midstream corporate contexts where the interests of the party

\footnotetext{
48. That is, $y\left(\theta_{b} a_{g}\right) \geq K$.

49. That is, where $b\left(\theta_{g} a_{b}\right)+t>b\left(\theta_{g} a_{g}\right)+t$, and $y\left(\theta_{g} a_{g}\right)>y\left(\theta_{g} a_{b}\right)$.

50. That is, $y\left(\theta_{g} a_{g}\right)-y\left(\theta_{g} a_{b}\right)$, provided that $b\left(\theta_{g} a_{g}\right)+t+y\left(\theta_{g} a_{g}\right)-y\left(\theta_{g} a_{b}\right) \geq b\left(\theta_{g} a_{b}\right)+t$.
}

51. See Aghion \& Bolton, supra note 13, at 480-83. The CTM runs the $V C$ control scenario with similarly equivocal results. Here first-best choices of action will follow only where the choice of $a$ that maximizes $y$ happens to be $a^{*}$, meaning that $V C$ 's incentives are perfectly aligned with the general maximizing result. Where the choice of $a$ that maximizes $y$ is not first-best there can be room for Pareto-improving renegotiation in the form of a bribe paid to the actor in control by the actor disadvantaged by the suboptimal choice of $a$. But once again, it turns out that the optimal choice $a^{*}$ does not result in every case. The model's reasonable assumption of a wealth constraint on $E$ 's part ( $V C$ provides all of $K$ ) substantially limits the possibility of renegotiation where $V C$ controls. Simply put, since $b$ and $t$ constitute $E$ 's entire wealth, $E$ lacks the resources to make the bribe. For $V C$ control to assure first-best results, then, the amount of $t$ has to be set high enough to give $E$ sufficient cash for the bribe. But this adjustment, in turn, returns us to the same place as the search for the first-best under $E$ control. As $t$ increases, projected investment returns to $V C$ fall short of $K$ at some point and $V C$ refuses to invest. $I d$. at 483-84. 
controlling the assets (usually $E$ or management) in the conduct of the business differ from those of contributors of capital (usually $V C$ or outside equity). This generalization is intuitively attractive, and it obtains even in the absence of bargaining costs, endowment effects, or collective action problems, the latter being the factor usually cited against midstream renegotiation of corporate contracts. ${ }^{52}$ The key to the result is the CTM's ascription of bargaining power to $E$. With that power, $E$ can negotiate $V C$ down to an ex post return $y$ that is less than $V C$ 's original investment $K$. That result kills the deal ex ante. In the real world, in the absence of fiduciary constraints, protective contract terms, or an immediately exercisable contingent control power to terminate $E, E$ will have significant bargaining power along the lines assumed in the CTM. The power arises in the first instance from the information asymmetries favoring $E$. Costs and other frictions in the way of $E$ 's removal enhance that bargaining power. As the power grows, $V C$ 's investment returns shrink.

It follows, logically enough, that $V C$ (or any other outside equity investor) needs one of three things - fiduciary protection, protective contract terms, or an immediately exercisable contingent control power. The CTM proceeds to the third of these alternatives.

\section{Control Transfer by Advance Specification}

The CTM employs the device of contingent control to solve the problem presented by the misalignment of the incentives of $E$ and $V C$ so as to yield results superior to that of Coasian renegotiation. Two additional assumptions have to be made to support the contingent control device's operation - that VC's returns are higher when a suboptimal choice of $a$ is made in $\theta_{g}$ states, and that $E^{\prime}$ s returns are higher when a suboptimal choice of $a$ is made in $\theta_{b}$ states. ${ }^{53}$ With this alignment, $V C$ will make a first-best choice in $\theta_{b}$ and $E$ will make a first-best choice in $\theta_{8}$, and a contract that accords control to $V C$ in $\theta_{b}$ and $E$ in $\theta_{g}$ will be optimal. These assumptions reflect an appealing intuition about the governance of startups. $E$ knows the business and should not be disturbed on $\theta_{g}$ scenarios. But since $E$ also derives private benefits from control of the business, $E$ is ill suited to make an optimal choice of business plan, or an optimal decision between termination and continuance, in $\theta_{b}$ states.

Since $\theta$ is unverifiable, the feasibility of a contingent control arrangement depends on the degree of correlation between $s$ and $\theta^{54}$ Given the requisite correlation, an optimal arrangement can be made

52. See, e.g., John C. Coffee, Jr., The Mandatory Enabling Balance in Corporate Law: An Essay on the Judicial Role, 89 COLUM. L. REV. 1618, 1664-65 (1989).

53. That is, that $y \theta_{g} a_{g}<y \theta_{g} a_{b}$ and that $b \theta_{b} a_{b}<b \theta_{b} a_{g}$.

54. Aghion \& Bolton, supra note 13 , at $484-86$. 
operational with relative ease in a world with a frictionless bankruptcy process. Thus does the CTM use a contract provision to avert difficulties stemming from the noncontractible nature of $\theta$. More particularly, $V C$ 's participation in the firm takes the form of debt. The realization of $s$ at $t=1$ is made a default/no-default event, with default occurring in a $\theta_{b}$ state. ${ }^{55}$ In the event of default, $E$ becomes bankrupt and $V C$ takes control, choosing the first-best $a$; in $\theta_{g}$ states there is no default and $E$ stays in charge. ${ }^{56}$ The same result can be effected with preferred stock (in a frictionless world). The realization of $s$ signaling an $\theta_{b}$ state triggers a redemption of $V C$ 's stock. If $E$ does not have a source of substitute capital, the duty to redeem causes bankruptcy and the same result as debt finance. ${ }^{57}$

\section{Implications}

The CTM has a number of intuitively attractive implications. The assertion that hard-wired contingent control transfers dominate over backroom renegotiations resonates well. The model also raises a pertinent question respecting the relative effectiveness of employment contracts and control transfer structures as means of channelling $E$ 's incentives in productive directions. The model implies that where crucial management choices - selections of $a$ from sets $A$ - are noncontractible due to problems of observability and verifiability and where $E$ enjoys private benefits, monetary incentive schemes based on firm profitability or stock market performance cannot be expected to import adequate discipline. Control structures allowing outsider investors to take actions that managers dislike in the event of poor firm performance, although a second-best solution, can be expected to do a more effective job of manipulating management incentives in productive directions. ${ }^{58}$

But the CTM's exclusive reliance on bankruptcy control transfer makes its transition to real world practice problematic. Bankruptcy, after all, is a drastic and costly step to have to take. The next section works past this sticking point.

55. The precedent model is in Jaime F. Zender, Optimal Financial Instruments, $46 \mathrm{~J}$. FIN. 1645 (1991).

56. Aghion \& Bolton, supra note 13 , at 487.

57. Provided there is not a significant amount of debt, which by definition is senior to $V C$ 's preferred stock, in the capital structure.

58. Mathias Dewatripont \& Jean Tirole, A Theory of Debt and Equity: Diversity of Securities and Manager-Shareholder Congruence, 109 Q.J. ECON. 1027-28 (1994). 


\section{The CTM and the Role of Senior Securities in Venture Capital Contracting}

This section moves the CTM a step in the direction of the real world practice described in Section A by relaxing some assumptions and expanding the menu of contractual devices implicating control and control transfer.

At first inspection, the data set out in Section A appear to suggest that the CTM's analytical structure lacks predictive power in the venture capital context. Recall that the most likely real world arrangement is shared control, and the next most likely is vesting of control in one party or the other. Contingent control transfer devices based on advance specification of an $s$ show up in a minority of the cases. But the data nonetheless instantiate the CTM's dynamic in significant ways. For one thing, the real world venture capital contracts' boardroom-control arrangements have to be read together with their financial provisions. These invariably provide for redemption of the preferred held by $V C$ in the intermediate term. This means that in an extreme $\theta_{b}$ state the contracts provide for a bankruptcy transfer of control, exactly as predicted by the CTM. On the other hand, the CTM has less immediate relevance with respect to control transfer in $\theta_{b}$ states where turn around remains a possibility and $\theta_{g}$ states where retention of $E$ will be profitable but suboptimal. But the framework can be adopted to assist our understanding of these situations.

The CTM's limitations stem from two components. First, it effects its contingent control transfer through a bankruptcy proceeding on the assumption that bankruptcy is frictionless. In the real world, bankruptcy costs are onerous. ${ }^{59}$ Venture capital practice shows us that these costs do not have to be incurred to effect a contingent control transfer. Second, the model limits itself to a contract term as it attempts to deal with the problem of noncontractibility. In so doing it hypothesizes an imperfect but plausible element of contractible subject matter: Although $\theta$ is unverifiable, the trigger $s$ is verifiable even though it is not a perfect proxy for $\theta$. But what of cases where no reliable $s$ exists, or where the parties cannot agree on one? In these cases some other control transfer device must be employed. The discussion that follows expands the menu of possibilities to include processes implicating control transfer and operating on an open-ended basis, dispensing with contractual triggers.

59. See, e.g., Edward I. Altman, A Further Empirical Investigation of the Bankruptcy Cost Question, 39 J. FIN. 1067 (1984) (estimating total bankruptcy costs to be $20 \%$ of the value of the firm). 


\section{Bankruptcy Versus Boardroom Control Transfer}

The CTM's assumption that control transfer occurs on a bankruptcy scenario can be relaxed easily by reference to standard tools of corporate law practice. In a close corporation context, changes of control in the boardroom can be contracted for in advance, even if the $V C$ takes preferred stock. $E$ and $V C$ simply enter into a "pooling agreement," contracting in their capacity as shareholders with respect to their future votes. In the context of the CTM, they would execute a voting agreement pursuant to which the occurrence of $s$ signaling an $\theta_{b}$ state would trigger the extension of a contingent irrevocable proxy from $E$ to $V C$. The proxy would give $V C$ the votes to elect a majority of the board and to remove incumbent directors. With boardroom control, $V C$ can choose the CEO who will choose $a^{*} \theta_{b}{ }^{60}$

60. See Dewatripont \& Tirole, supra note 58. Although still a model denominated as a debt-equity model, it nonetheless captures the dynamic of a boardroom control transfer. This is another two-period contingent control model. Unlike the Aghion-Bolton model, this one includes outside debt and outside equity interests. Here, at $t=0$, outside financing and incentive compensation arrangements are worked out and management chooses an effort level $e$. The level of $e$ will be either high or low, with high $e$ producing higher returns in later periods but resulting in the incurrence of a utility cost $U$ to the managers. At $t=1$ the firm reports its first period profit, $n p l$, a verifiable amount that is determined by $e$, but which is not a sufficient statistic for $e$. In addition, a signal $s$ is realized at this point. The distribution of signal $s$ also is determined by $e$, and $s$ is a sufficient statistic for the profit to be realized at $t$ $=2, n p 2$. But $s$ is noncontractible and management compensation accordingly cannot be made directly contingent on it.

This model's distinguishing assumption is that the firm's capital structure accords decisionmaking power to either the outside debtholder or the outside equityholder at a critical moment. More specifically, immediately after $t=1$, the outside holder accorded this control power takes action $a$, which can either be acquiescence and continuance $C$ in present management operations or stoppage $S$ of management's continued pursuit of its business plan. Stoppage $S$ can entail any number of subsequent actions, including liquidation, sale of a division or other downsizing, or redirection of investment policy. Whatever the action taken, for any given signal $s, S$ entails less risky subsequent management than $C$, the probability distribution of which has fatter upper and lower tails. At $t=2, n p 2$ is realized and income is shared in accordance with the contracts in the capital structure. Id. at 1031-34.

$\begin{array}{llll}\begin{array}{l}\text { Investment, } \\ \text { Contract }\end{array} & \begin{array}{l}\text { Realization of } n p 1 \\ \text { and signal s }\end{array} & \text { Realization of } n p 2 \\ \mathrm{t}=0 \quad \begin{array}{c}\text { Choice } \\ \text { of } e\end{array} & \mathrm{t}=1 & \text { Action } a \text { taken } & \mathrm{t}=2\end{array}$

The model examines two possible compensation incentive schemes for $E$ : one constituted of private benefits only and the other including a salary. The purpose of any such scheme is of course to induce $E$ to choose a high level $e$. But given the model, and in particular the noncontractibility of $s$, the optimal arrangement must include a possibility of punishment in the form of a control transfer to outsiders who have the power to choose action $S$. Since management always prefers $C$ to $S$ (whether or not $C$ is efficient), a structure that increases the possibility of such intervention as $n p l$ and $s$ decline lends management an incentive to choose a high level of $e$, maximizing the possibility of a choice of $C$ despite the cost of $U$ thereby incurred. Given this, any bonus payments should be based on earnings results of both $n p 1$ and $n p 2$, with the $n p 2$ target level rising as the $n p 1$ amount declines. $I d$. at 1035-39. 
The two different methods of control transfer, in the boardroom and through liquidation, are suited to different business outcomes. One accordingly would expect to see both employed in real world arrangements. Significantly, the CTM interpolates only two business situations - the selection of $a$ from the range $A$ in $\theta_{g}$ and $\theta_{b}$ states. In practice, there will be an open-ended range of such future choices: $a$ from $A, b$ from $B, c$ from $C$, and so on, and $\theta_{g}$ and $\theta_{b}$ will cover a range of outcomes. When such a choice concerns a change in the business plan or the replacement of key personnel, whether in an $\theta_{g}$ or $\theta_{b}$ state, the boardroom control transfer mode is indicated. The liquidation trigger, in contrast, is better suited to severe $\theta_{b}$ states calling for disinvestment. ${ }^{61}$

Another distinction between control transfer by redemption and bankruptcy and control transfer by boardroom election should be noted. The former mode of transfer implies $V C$ financing by a senior security, whether debt or preferred. That is because when redemption causes insolvency, control devolves to $V C$ because it holds a liquidation preference over $E$ in the bankruptcy distribution. Boardroom control transfer can be (and often is) effected in a firm funded entirely with common stock and does not implicate an insolvency proceeding. This implies a real world preference for transfer by boardroom control transfer provisions over control transfer through redemption and liquidation if only because bankruptcy is costly in the real world. ${ }^{62}$ But the prediction must be qualified because redemption does not necessarily lead to a bankruptcy proceeding. If the going concern retains value, the triggering of the redemption right can become the occasion for renegotiation between $V C$ and $E$. Since $V C$ now has the option of forcing insolvency, it comes to the table with cognizable bargaining power. ${ }^{63}$

\section{Debt, Preferred, or Common?}

The foregoing discussion gives rise to two further questions about venture capital contracts: Why preferred stock and not debt? And, why preferred and not common stock? To ask the former question is to note that the periodic payment properties of noncumulative convertible preferred can be mimicked in part with a convertible

61. For a model amplifying the efficiency properties of creditors' liquidation rights, see Oliver Hart \& John Moore, Default and Renegotiation: A Dynamic Model of Debt, 113 Q.J. ECON. 1 (1998).

62. See supra text accompanying note 59 .

63. If the going concern retains more value still, $E$ can refinance and pay off $V C$. If $V C$ is the party positioned to choose $a^{*}$ the result is suboptimal. 
income bond ${ }^{64}$ Such a security would import the same high-powered incentives to $E$ as does convertible preferred. Where the preferred holder gets an intermediate term right to put the stock back to the issuer, the convertible bondholder gets the substance of that right with intermediate term maturity. Either way, $V C$ gets a liquidation preference that has the effect of raising the cost to $E$ of poor performance. ${ }^{65}$ Packaging this convertible senior security as debt would carry two additional benefits for $V C$ : a higher and harder bankruptcy priority and a chance for a tax deduction on interest payments. $^{66}$

But American corporate law holds out a significant disincentive to the packaging of venture capital participation as debt. $V C$ s commonly do more than monitor their investments and facilitate the hiring of professional managers by their portfolio companies; they often control or influence the decision to replace the CEO and make other key business decisions. ${ }^{67}$ To the extent that the transaction structure holds out the prospect of significant $V C$ input in management, including the power to specify business results, $V C$ should act in the capacity of an equity securityholder at the time it exercises such control power. A debtholder who exercises control power in that capacity loses its limited liability status, and could be personally liable to other creditors of the firm or even to $E$ in the event its management decisions work out badly. ${ }^{68}$ Debtholders can influence control while retaining limited liability only indirectly, by specifying default events ex ante in negative covenants. In order to structure meaningful control by a debtholder, then, a basis of contractible subject matter is needed. In the alternative, a contingent control transfer to a debtholder can be effected without risk of unlimited liability on the scenario posed by the CTM - default, bankruptcy, emergence with $V C$ in charge,

64. Kaplan \& Strömberg, supra note 12 (working paper at 18 ), report that preferred dividends are cumulative in only $46 \%$ of the cases. This suggests that periodic income is not a primary concern here.

65. Klausner \& Litvak, supra note 9 (working paper at 10 ).

66. For the tax deduction, a firm promise to pay would be necessary. The income contingency would not strengthen the case. See Fin Hay Realty Co. v. United States, 398 F.2d 694, 696 (3d Cir. 1968).

67. Klausner \& Litwak, supra note 9 (working paper at 4-5).

68. The classic case, Martin v. Peyton, 158 N.E. 77 (N.Y. 1927), concerns a loan to a partnership. The liability of bank lenders to small businesses is the subject of leading cases in recent years. See, e.g., K.M.C. Co., Inc. v. Irving Trust Co., 757 F.2d 752 (6th Cir. 1985); State Nat'l Bank of El Paso v. Farah Mfg. Co., 678 S.W.2d 661 (Tex. App. 1984). See generally Margaret Hambrecht Douglas-Hamilton, Creditor Liabilities Resulting from Improper Interference with the Management of a Financially Troubled Debtor, 31 BUS. LAw. 343 (1975). There is of course a way to deflect this risk for a debt holding $V C$ with control power. If the $V C$ is a human being, one forms a wholly owned shell corporation or limited liability company to hold the debt; if the $V C$ is a corporation, it forms a shell wholly owned subsidiary. Both steps are costly, and there remains a residual risk of veil piercing. 
presumably as the holder of all of the equity of a reorganized firm. But as noted above, bankruptcy costs make this a second-best alternative in real world planning.

The preferred/common stock choice turns in part on priorities. In the CTM, $E$ takes periodic return in salary $t$. If $V C$ takes its position in common stock and $E$ also holds some common as an incentive device, $V C$ and $E$ would share what is left of $r$ at $t=2$ pro rata, which would mean a double dip for $E$. If $V C$ holds stock with an income preference, $V C$ takes $r$ - $t$, to the extent of the preference and any common stock held by $E$ would pay in addition to $t$ only to the extent that $V C$ 's preference is satisfied fully. More generally, in small business planning, preferred and debt are standard tools for compensating financial participants where the entrepreneurs take much of their share of free cash flows in the form of salary payments. ${ }^{69}$ In addition, on downside scenarios preferred means a priority to whatever is left in liquidation. ${ }^{70}$ Finally, there is an exogenous regulatory concern. Regulated institutional investors participating in the venture capital partnership, such as insurance companies, will prefer to take their equity in the form of convertible senior securities so as to satisfy legal constraints on the amount of common stock in their investment portfolios. ${ }^{71}$

\section{Shared Control}

We turn now to the CTM's assumption that even though $a^{*}$ cannot be specified in advance, the parties can, to the extent they deem $s$ reliable, contract ex ante to change control for the purpose of making the selection of $a^{*}$ more likely. This setup is descriptive of innumerable instances in practice. Financial contracts routinely utilize such imperfect but verifiable signals. Such real world manifestations of $s$ are the accounting and performance data utilized in the drafting of representations, closing conditions, covenants, and default triggers.

69. F. HODge O'Neal \& RoBert E. ThOMPSON, O'Neal's Close Corporations: LAW AND PRACTICE $\S 2.21$ (3d ed. 1998). Sahlman, supra note 21 , at 510, suggests an additional tax reason. The overhang of preferred rights lowers the value of the common for tax purposes, permitting $E$ to buy the common stock at low prices without reporting taxable income on the differential between the amount paid and the greater amount paid by $V C$. See also Klausner \& Litvak, supra note 9 (working paper at 9).

70. One could presumably replicate the preferred stock outcome by placing in $V C$ a combination of common stock and debt. This would, however, mean a process burden on $V C$ in the event of exercise of control to make it clear that it acted in the capacity of a common stockholder. A residual litigation risk would endure even so.

71. Incidence of insurance company participation in venture capital firms varies from year to year. PAul A. Gompers \& JOSH LeRner, The Venture CAPITAl CyCle 8-9 .tbl.1.1 (1999), shows that insurance company and bank participation levels in venture capital partnerships amounted to $16 \%$ in $1978,15 \%$ in 1987 , and $18 \%$ in 1995 , but $4 \%$ in $1979,6 \%$ in 1991 and $1 \%$ in 1997 . Public and private pension funds consistently are the largest investors, putting in $40 \%$ of the capital in 1997. 
Indeed, $15 \%$ of the cases in Kaplan and Strömberg's sample specify boardroom control transfers to $V C$ based on a financial or performance $s$.

More difficult contracting problems arise where governance intervention needs to be specified but $s$ is unreliable, unverifiable, or there is no $s$. If we stay within the confines of the CTM, the lack of $s$ means that nothing exists to trigger a transfer of control and $V C$ has to let the investment ride until $t=2$. At that point, given a $\theta_{b}$ state, $V C$ 's dividend and liquidation priorities assume paramount importance, but the payoff may be suboptimal.

Let us abandon the CTM's hard assumptions respecting payouts to $E$ and $V C$ and the choice of action $a,{ }^{72}$ and instead assume that the choice among $a_{g}$ and $a_{b}$ on $\theta_{g}$ and $\theta_{b}$ states depends on complex and probabilistic factors so that there is no clear cut connection between $E$ or $V C$ control and the optimal choice of $a$. Although it always is optimal in the model to leave $E$ in charge on $\theta_{g}$ states, now it is plausible to suggest that $V C$ could effect $a^{*} \theta_{g}$ simply by removing $E$ and undertaking a search for a substitute chief executive better suited to grappling with the problems at hand and bringing about $a^{*}$. But because the decision that a substitute is better fitted to effect $a^{*} \theta_{g}$ follows from a complex business judgment, there may be no basis with which to provide for this control allocation ex ante. The same sort of problem could arise in an $\theta_{b}$ state where correction remains possible, with the new CEO being charged with the job of turning the operation around. Such scenarios are better suited to treatment through the operation of a contractually instituted governance process than through advance contractual specification of a clear-cut outcome.

Joint control suggests itself as a solution in these cases. ${ }^{73}$ In Aghion and Bolton's CTM, joint control is defined very narrowly to mean that either $E$ and $V C$ both agree, or that in the event of disagreement, $E$ will make a one-time, take-it-or-leave-it offer to $V C$ as to choice of $a$; in the event that $V C$ refuses the offer, deadlock results and the returns to both parties are zero. Such a joint control set up means that hold ups are a possibility in every case. As a result, in Aghion and Bolton's model, joint control always is dominated by unilateral or contingent control. $^{74}$

72. That is, that $y \theta_{g} a_{8}<y \theta_{g} a_{b}$ and that $b \theta_{b} a_{b}<b \theta_{b} a_{g}$

73. For a formal model of joint control in venture capital contexts in which control is a continuous variable to be adjusted through different contract provisions, see Andrei A. Kirilenko, Valuation and Control in Venture Finance, 56 J. FIN. 565 (2001). This model, by opening up control to a range, moves the formal theory of the firm closer to Kaplan and Strömberg's real-world picture. It does not, however, specify any direct connections between its formal terms and real world institutions.

74. Aghion \& Bolton, supra note 13, at 486. 
But joint control is not dominated if we change the CTM's assumptions. Contingent control dominates only because the model assumes a reliable $s$. Without a reliable $s$, the negotiating parties would have a high-powered incentive to find a way to contract around the deadlock the model assumes. It comes as no surprise that any number of such devices show up in real world business planning practice. For example, $V C$ could contract for a seat on the board of directors. ${ }^{75}$ This ameliorates information asymmetries and imports voice without the power to direct results $-V C$ can attempt to influence $E$ without having a power to specify the choice of $a$. Alternatively, the parties could contract for fifty-fifty boardroom representation and interpolate a deadlock breaker, such as arbitration. Since this would be contingent on their failure to agree, it would not depend on the identification of an $s$. Such sharing arrangements are common in the world of contracts among equity participants in small businesses. ${ }^{76}$ Although not perfect, such solutions do amount to a plausible second best given the absence of a contractible contingency clearly indicating that control should be vested in $E$ or $V C$.

With this we return to Kaplan and Strömberg's results and the practice of shared control in venture capital startups. ${ }^{77}$ The contracting pattern suggests an interesting modification of the CTM's setup. As noted, contracts providing for contingent control transfer to the $V C$ upon an $s$ specified in advance are a minority. But this point also confirms the theoretical prediction that contracts in this context will manifest strategies for dealing with noncontractible subject matter. ${ }^{78}$ The small number of such provisions bespeaks a judgment that the available signals are unreliable. It appears that both $V C$ and $E$ prefer to grapple with unverifiable facts attending $\theta_{b}$ states in the black box of the boardroom.

75. Venture capital transactions include a separate "Investor Rights Agreement" entered into between the issuer and individual purchasers of preferred. These contracts customarily include a right to attend board meetings in a nonvoting capacity. See Craig E. Dauchy, Venture Capital Financings, in DOING DEALS 2000: UNDERSTANDING THE NUTS AND Bolts of Transactional Practice 233, 301 (PLI Corp. L. \& Prac., Course Handbook Series No. 1167, 2000).

76. O'NEAL \& ThOMPSON, supra note 69 , at $\$ \S 9.0-.38$.

77. For a contrasting discussion of shared control arrangements, see Armando Gomes \& Walter Novaes, Sharing of Control as a Corporate Governance Mechanism (SSRN Elec. Paper Coll. No. 277111, 2001), at http://papers.ssrn.com/abstract=277111. Gomes and Novaes model shared control as a governance mechanism for a firm with a dispersed minority shareholder interest. They hypothesize two blockholders who together control management decisions but cannot act unilaterally, and they show that in some circumstances such an arrangement could be superior to either of control by a single blockholder or widely dispersed shareholding.

78. The practitioner literature shows that this is effected by a shareholder voting agreement pursuant to which, in the event that performance targets are not met, $E$ promises to vote for additional directors nominated by $V C$. Dauchy, supra note 75 , at 243. 
During the noncontractible period between $t=0$ and $t=2, V C$, instead of waiting for a verifiable signal, takes a noncontrolling position inside the firm's boardroom. In the boardroom there are three directors, $E, V C$, and a neutral third actor selected by both. So long as the three agree, control is shared. In the event of disagreement between $V C$ and $E$, the mutually selected third director holds the balance of power. By hypothesis, $V C$ and $E$ will compete to influence the third director. Suppose performance has been mediocre and $V C$ would like to remove and replace $E$ as CEO. If the third director is motivated to enhance firm value and $V C$ persuades the third director that the move is necessary for achievement of an $\theta_{g}$ state, $E$ is out. At the same time, $E$ also has access to the third director and can state a defense. $^{79}$

Compare the more limited menu of control transfer devices in the CTM. There, if no transfer occurs by advance specification but performance incentives turn out to be dysfunctional, you contract into the optimal performance state only by means of a Coasian bribe. Interestingly, this item is always on the real world menu. Nothing stops a $V C$ in the tripartite shared-control arrangement from making a similar bribe either to the third director or to $E$. Nor does anything stop the third director from initiating this discussion and holding out for a side payment. But a persuasive substantive pitch to the third director costs $V C$ less than a bribe. By hypothesis, then, the ideal third director has a strong reputational interest in being seen as an impartial, expert maker of good-faith business judgments who pursues firm value from a neutral stance and is impervious to Coasian bribes. This lets the firm reach $a^{*}$ without barriers stemming from ex ante wealth endowments or insufficient expected value of the project in $\boldsymbol{\theta}_{b}$. For the reputational constraint to work, the third director would have to be an actor known in a business community common to both $E$ and $V C$. Here, as in Gilson and Black's description, the real world pattern of close geographic proximity between $E$ and $V C$ would be facilitative: the third director should also live in the neighborhood. Similar reputational concerns may constrain the $V C$ before forming an alliance with the third director against $E$. The $V C$ who engineers too many $E$ replacements or, worse, abuses its power, can be shut out of future deals with the best $E$ s. $^{80}$

79. For a comparison venture capital form, which provides for $V C$ control on a three out of five basis, see 1 MiCHAEL J. HALloran ET AL., VENTURE CAPITAL AND PUBLIC OFFERING NEGOTIATION \& 8-23 (3d ed. 2000).

80. Black \& Gilson, supra note 17 , at 262-63; Sahlman, supra note 7, at 513; see also Kirilenko, supra note 73, at 570 (noting that "venture capital firms are greatly differentiated by reputation"). 


\section{Implications}

The shared control structure's real world dominance over the alternative of $V C$ control or hardwired control transfers suggests that $E$ s have significant but not decisive bargaining power, presumably because $V C$ s compete to finance the most promising entrepreneurs. It also suggests that an arrangement positioning cooperation in the shadow of a threatened control transfer has productivity advantages. Certainly, there is evidence of significant CEO turnover in the venture capital field. ${ }^{81}$ Thus, to the extent the venture capital interest can be protected satisfactorily without outright boardroom control, one would expect shared control to dominate over venture capitalist control.

A recent story in the business press reinforces this description of shared control in venture capital portfolio companies. Robert E. Davoli, a $V C$ with a notable number of wildly successful high technology investments in the years preceding 2000, also is known for an aggressive posture respecting the tenure of his $E$ s. He has fired six of twenty-four in a five-year period. The result is a reputation as an impatient $V C$, in contrast to the more passive postures of the "instant" $V C$ s who, chasing the trend, entered the business in the late 1990s. This is said to make Davoli a throw back to the heroic days of venture capital in the 1960s, when pioneers like Arthur Rock and Thomas J. Perkins took a hands-on role. Meanwhile, Davoli is said to be subject to a constraint when attacking an $E$ for missing a performance target. He must first mobilize the board. ${ }^{82}$

Even as this story describes a world of shared control, it suggests caution with the foregoing account. First, venture capital arrangements may have evolved in history, with $V C$ control being the practice in an early phase and shared control becoming more prominent as more capital came to pursue fewer deals with a more sophisticated generation of Es. Second, shared control may mean different things in different portfolio companies. Many factors can come to bear when the third director is selected. $V C$ is likely to have

81. GOMPERS \& LERNER, supra note 71 , at $176-78$, reports turnover in 40 out of 220 venture capital rounds in their data set. M.T. Hannan et al., Inertia and Change in the Early Years: Employment Relations in Young, High Technology Firms, 5 INDUS. \& CORP. CHANGE 503 (1996), finds that in the first twenty months following a firm's initial round of venture capital finance, $20 \%$ of firms replace $E$ with a nonfounder CEO; the percentage goes up to $40 \%$ after forty months and $80 \%$ after eighty months. See also Klausner \& Litvak, supra note 9 (working paper at 6).

82. John A. Byrne, How a VC Does It, BUs. WK., July 24, 2000, at 97. More generally, "high-reputation $V C$ s tend to replace CEOs more often than low-reputation $V C$ s do." Klausner \& Litvak, supra note 9 (working paper at 6). For a discussion of the problems an $E$ faces in choosing a $V C$ and a description of a reputational market for $V C$ services, see $D$. Gordon Smith, Venture Capital Contracting in the Information Age, 2 J. SMALL \& EMERGING BUS. L. 133 (1998). 
the more extensive network of potential candidates. Information asymmetries and differentials in bargaining power and skill could mean that the "independent" third director is highly susceptible to the influence of the $V C$ (or, as seems less likely, to the influence of $E$ ). If negotiations work systematically to favor $V C$ influence, the real world of shared control may not be materially dissimilar from that of the standard picture of $V C$ control.

Consider in this regard a technical point respecting the control sharing mechanism. As a matter of contract planning, it is never enough for $E$ and $V C$ to agree to agree on the third director. One must also provide for the possibility that $E$ and $V C$ might fail to agree on a candidate.$^{83}$ Without a deadlock-breaking arrangement at the selection stage, a board of two can emerge and make costly deadlock a possibility. The standard close corporation drafting solution is to provide for the intervention of a neutral arbitrator at this point. ${ }^{84}$ The legal literature suggests that a low-cost but somewhat arbitrary alternative approach is utilized in some venture capital deals. Under this, the charter provides that $E$ 's class of stock elects one director, $V C$ s class of stock elects one director, and the third director is elected by all the stock, voting as a single class. ${ }^{85}$ Assuming that $E$ and $V C$ each have one vote per share and do not hold exactly the same number of shares, the result in a case of disagreement is that the winning third-seat candidate will be nominated by the actor with the larger absolute number of shares. Absent some other arrangement constraining the exercise of voting power, this means that in the event of disagreement, the party with the share voting majority controls all significant firm decisions. According to Kaplan and Strömberg's numbers, this contracting solution favors the $V C$ in the majority of cases.

We have assayed the dynamics of shared control without asking a fundamental question: Why have shared control in most cases, full $V C$ control in a significant minority of cases, and full $E$ control in a smaller minority of cases? What factors distinguish the three classes of transactions? On a standard agency cost analysis we should expect to see greater control rights in $V C$ in transactions holding out greater information asymmetrics and adverse selection problems. ${ }^{86} \mathrm{~A}$ line of

83. One also needs to control the size of the board. The practitioner literature contains an exemplar of a $V C-E$ voting agreement containing a provision requiring unanimous consent to increase the size of the board. Lawrence B. Low, Venture Capital Agreements, in NuTS AND Bolts OF FInANCIAL PRODUCTS: UNDERSTANDING THE EVOlVING WORLd OF Capital Market and Investment Management Products 313, 413 (PLI Corp. L. \& Prac., Course Handbook Series No. 1035, 1998).

84. See Ringling Bros.-Barnum \& Bailey Combined Shows v. Ringling, 53 A.2d 441 (Del. 1947); O’NEAL \& THOMPSON, supra note 69, at $\$ \S 9.0-38$.

85. Dauchy, supra note 75 , at 316.

86. Malcom P. Baker \& Paul A. Gompers, Executive Ownership and Control in Newly 
theoretical economics expands on this point in detail. Thomas Hellman focuses on bargaining power and productivity variables. $\mathrm{He}$ asks why $E$ would surrender control in the first place, since surrender of control creates the possibility that at some point after startup $V C$ will terminate $E$ as CEO and substitute a professional manager ${ }^{87}$ If $V C$ always has all the bargaining power, the question is easily answered $-E$ has no other way to access capital. But, notes Hellman, a puzzle arises in a world where $E$ s can access alternative (and more passive) sources of capital. Alternatively, an $E$ with an attractivelooking project acquires bargaining power when multiple $V C$ s compete for the opportunity to participate. In Hellman's model, $V C$ control is more likely, and replacement of $E$ more frequent, where professional management substitutes add value, $E$ s tend to be unproductive, Es derive low private benefits from control, and $V C \mathrm{~s}$ have greater bargaining power ${ }^{88}$ In the alternative, Kirilenko offers an incomplete contracts model which shows that more control comes to $V C$ with higher degrees of adverse selection. In this model, as control is surrendered to $V C, E$ can be expected to take a give back in the form of more advantageous financial terms. ${ }^{89}$

\section{The Preferred Stock Problem IN THE Venture CAPITAL CONTEXT}

The theoretical case for preferred stock as a financing vehicle for venture capital, thus described, is robust. But problems inhere in the legal framework that encases preferred stock. This Part describes those problems and the contractual solutions that have evolved in the venture capital context. When we emerge from this discussion, venture capital preferred will still be in a robust condition. But it will have a few weaknesses in need of attention.

\section{A. The Preferred Stock Problem}

The "preferred stock problem" is wrought into the historical performance of publicly traded preferred. The classic description of the problem can be found in Graham and Dodd's treatise on corporate finance. Graham and Dodd warned value investors against investment in preferred stock, observing that it did not behave like a senior security should on all downside scenarios. The dividend

Public Firms: The Role of Venture Capitalists (SSRN Elec. Paper Coll. No. 165173, 1999), at http://papers.ssrn.com/abstract $=165173$.

87. Hellman, supra note 13 , at 58.

88. Id. at 60 .

89. Kirilenko, supra note 73 , at 579-80. 
preference worked well in good times; the liquidation preference maintained senior status in extreme distress situations. The problem lay in the middle, with the issuer who found itself struggling to gain or maintain a position in a hostile product market. The struggling issuer could cut off periodic payments to the preferred indefinitely, putting it in the position of a residual interest holder, even as the issuer kept current its interest and principal payments on subordinated debt. Avoidance of a bankruptcy filing gave the issuer a powerful incentive to maintain the cash flows on the debt. ${ }^{90}$ It had no comparable incentive to keep current on the preferred. Contractual provision for the cumulation of missed preferred dividends did not correct the incentive problem. As between allocating a dollar to a preferred dividend or enhancing the business plan, the struggling issuer always chose the latter. An overhang of preferred dividend arrearages could be dealt with later, after a turnaround in the product market. Often that turnaround never happened.

Even the preferred of the most highly rated issuers failed to pass inspection in Graham and Dodd's risk-averse framework. Highly rated preferred, they said, offered only the slightest step up in yield over comparable subordinated debt. This did not adequately compensate for the contractual risks. ${ }^{91}$ The preferred stock form, Graham and Dodd concluded, was "fundamentally unsatisfactory." Anticipating the CTM, they opined that preferred made sense only under a contract providing that suspension of the payment stream triggered a transfer to the preferred of voting control over the firm. But they entered a caveat here too. Even if the contract provided for voting control, it was not safe to assume that it would be "intelligently utilized" 93 by a dispersed group of small holders.

Graham and Dodd's negative analysis has proved predictive. Usage of preferred as a mode of finance by mature firms declined markedly in the latter part of the twentieth century. Publicly issued preferred persists in substantial volume only in the capital structures of firms in regulated industries, such as banks and public utilities. For these firms, preferred issues make cost sense as a means of satisfying regulatory mandates to increase the base of equity capital. ${ }^{94}$

Opinions nonetheless will differ as to whether Graham and Dodd's blanket disapproval should be taken seriously today. Their depression-

90. Benjamin Graham et al., Security analysis: Principals and Technique 379 (4th ed. 1962).

91. Id. at 382; see also SIDNEY COTTLE ET AL., GRAHAM AND DODD'S SECURITY ANALYSIS 470-74 (5th ed. 1988).

92. GRAHAM ET AL, supra note 90 , at 375 .

93. Id. at 381 .

94. Richard A. Brealey \& Stewart C. Myers, Principles of Corporate FINANCE 392-93 (6th ed. 2000). 
era risk aversion rings hollow in the context of the risk neutrality of modern financial economics. Surely, says the contemporary observer, actors in the capital markets will have devised solutions to any contracting problems. The contemporary preference for subordinated debt over preferred should be attributed to the tax system and the agency cost advantages of debt capitalization ${ }^{95}$ rather than to any intrinsic infirmity in the preferred stock form. ${ }^{96}$ Interest payments are deductible by the issuer where preferred dividend payments are not, making debentures the cheaper mode of financing for issuers with substantial income tax liabilities ${ }^{97}$ - so much cheaper that the cost balance tends to tip only in the case of regulated issuers.

Observers schooled in corporate law will be less quick to discard Graham and Dodd's negative judgment on the preferred stock contract. The legal track record of publicly issued preferred, viewed from the investor's point of view, has been as dismal as was the financial performance of public utility preferred issues in the depression era. ${ }^{98}$ To a reader of case law on preferred stock contracts, Graham and Dodd got it exactly right: absent voting control and a means of surmounting collective action problems in its exercise,

95. Michael C. Jensen, Agency Costs of Free Cash Flow, Corporate Finance, and Takeovers, 76 AMER, ECON. REV. PAPERS \& PROC. 323 (1986).

96. Cf. Robert Heinkel \& Josef Zechner, The Role of Debt and Preferred Stock as a Solution to Adverse Investment Incentives, 25 J. FIN. \& QUANT. ANAL. 1 (1990) (showing that preferred creates incentives for the firm's common holders to invest, and thus ameliorates the underinvestment problem that follows from the issuance of debt; a new issue of preferred counters the agency costs of debt, and thereby not only enhances the firm's debt capacity but increases the overall value of the firm).

97. ViCTOR BRUDNEY \& WILliam W. BRATTON, BRUDNEY \& CHIRELSTEIN's Cases AND MATERIALS ON CORPORATE FINANCE $337-38$ (4th ed. 1993). Some of this relative disadvantage is made up by the intercorporate dividend exclusion, under which corporate holders of preferred can exclude a substantial percentage of dividends received from their corporate tax bases. I.R.C. $\$ \$ 243,244(1990)$. The result is that preferred, particularly if issued by a high-grade public utility, can offer an attractive opportunity to insurance companies and other corporate institutional investors. The tax benefit means a lower yield and cost of capital to the issuer. Donald E. Fischer \& Glenn A. Wilt, Non-Convertible Preferred Stock as a Financing Instrument 1950-1965, 23 J. FIN. 611 (1968). Short-term floating rate preferred with dividend rates tied to short-term interest rates also makes use of the intercorporate dividend exclusion. This paper is often issued by banks and sold to corporations with excess cash available for short-term investment, for which it makes an attractive alternative to short-term debt instruments.

Another tax dodge also must be noted. In the mid-1990s, investment bankers put the corporate trust device to use in inventing tax deductible preferred. Here the corporation raising the capital issues bonds to a special purpose trust. The trust in turn raises the capital to pay for the bonds by issuing preferred stock to corporate taxpayers. The ultimate credit on the deal takes an interest deduction while the ultimate sources of capital get the intercorporate dividend exclusion. By the end of 1997, more than 285 of these issues were outstanding; they had raised $\$ 27$ billion. Arun Khanna \& John J. McConnell, MIPs, QUIPs AND TOPrs: Old Wine in New Bottles, 11 J. APPLIED CORP. FIN. 39 (1998).

98. See Robert M. Blair-Smith \& Leonard Helfenstein, A Death Sentence or a New Lease on Life? A Survey of Corporate Adjustments under the Public Utility Holding Company Act, 94 U. PA. L. REV. 148, 150-51, 162-69 (1946). 
preferred holders are vulnerable to issuer opportunism. In bad times, they are the victims of opportunistic recapitalizations and one-sided renegotiations pursuant to which their preference rights are stripped for the benefit of the common stock. ${ }^{99}$ In good times, contractual legerdemain incident to mergers and acquisitions can lead to the same results, again transferring value from their pockets to those of the common stockholders.

Furthermore, preferred's legal position deteriorated markedly over the course of the twentieth century. Prior to 1940, some of these opportunistic transactions were held by state courts to violate constitutional property rights. But that "vested rights" theory of judicial protection fell out of favor. This can be attributed in part to the ascendency of realist and collectivist jurisprudence during the New Deal. ${ }^{100}$ Charter competition also played a role. Delaware has seen that the interests of the managers who choose states of incorporation are aligned with the common stockholders against preferred and other senior security holders and shaped its case law accordingly. ${ }^{101}$ Today's cases hold out no fiduciary or other protective doctrine to substitute for the defunct vested rights approach. As a result, public preferred holders have to rely on the literal terms of their contracts to protect against issuer opportunism. From the evidence of the litigated cases, the contracts never evolved so as to close all the loopholes and provide reliable protection. ${ }^{102}$

From the legal perspective, then, the eclipse of preferred as a financing vehicle for mature firms may reflect dysfunctional contracting in addition to tax disadvantages. Under this view, it is not safe to assume that the legal framework encasing a given mode of

99. It should be noted that a surrender of rights by a class of preferred in connection with a distressed issuer's recapitalization is not per se unfair. Sometimes the common stock has rights too, as where both the preferred and the common have to vote as a class to approve a charter amendment or merger that will make the firm as a whole more valuable. In such a case, the common will not support the transaction unless it is allocated a part of the proceeds. Responsible managers do their best to give the common enough to garner its support but otherwise respect the rights of the preferred. The classic case is Goldman v. Postal Telegraph, Inc., 52 F. Supp. 763 (D. Del. 1943).

100. See Davison v. Parke, Austin \& Lipscomb, 35 N.E.2d 618, 622 (N.Y. 1941); NORMAN D. LATTIN, THE LAW OF CORPORATIONS 573-82 (2d ed. 1971). The legal landscape surrounding bonds also changed drastically during the course of the twentieth century. Fiduciary duties to bondholders today are hypothesized by law review commentators. No significant case supports them. In the $1920 \mathrm{~s}$, fiduciary duties to bondholders were everyday subject matter in litigated cases. See, e.g., Charles H. Haines, Jr., Comment, Corporations - Modification Provisions of Corporate Mortgages and Trust Incentives. 38 MICH. L. REV. 63 (1939). 1940).

101. The leading Delaware case is Federal United Corp. v. Havender, 11 A.2d 331 (Del.

102. Alfred F. Conard, Corporations in Perspective 266 (1976); Victor Brudney, Standards of Fairness and the Limits of Preferred Stock Modifications, 26 RUTGers L. ReV. 445 (1973); Lawrence E. Mitchell, The Puzzling Problem of Preferred Stock (And Why We Should Care About It), 51 BUS. LAW. 443 (1996). 
finance has evolved so as to foster first-best contractual risk allocations. ${ }^{103}$ For preferred holders, per Graham and Dodd, the legal environment makes voting control the sine qua non of adequate protection. There results a sticking point. Mature issuers will be unwilling to concede voting control to senior security holders whose capital contribution amounts to a minority proportion of the firm's equity base. Unless the contract is carefully drafted to vest the preferred with critical vetoes, the contract can be unilaterally amended to remove or modify the preferred's rights to the benefit of the common. ${ }^{104}$ Preferred stock contracts drafted with the degree of precision necessary to assure $100 \%$ protection against such ex post stripping of value have been the exception and not the rule. A species of bargaining impasse results - an impasse making the publicly issued preferred of a mature firm unlikely to carry an advantageous price when compared to a subordinated debenture.

The subsections that follow describe the preferred stock problem in greater detail. The discussion picks up the contracting pattern described in Part I, distinguishing injuries that stem from the absence of control of the boardroom from injuries that stem from the absence of a majority of the votes at shareholders' meetings. Section B will return to venture capital preferred to gauge the degree of success $V C s$ have had in solving the problems.

\section{Control in the Boardroom}

Recall that in the CTM, the firm's central governance problem concerns the allocation of the power to select a maximizing course of action $a^{*}$ given suboptimal incentives on the part of the holders of the firm's common equity. In practice, whether such a critical choice implicates investment policy, dividend policy, the decision to sell or liquidate the firm, or amendment of the firm's charter, the legally constituted governance structure of the corporation vests the power to make the decision in the boardroom. In some cases, as with mergers (and asset sell-outs), liquidations, and charter amendments, approval of the shareholders also must be bestowed at a second stage. But the board still controls the agenda and acts as the first-stage gatekeeper. So, to return to the problem described by Graham and Dodd, when an issue of preferred loses value because it pays no dividends at a time

103. For expositions of this view, see Marcel Kahan \& Michael Klausner, Standardization and Innovation in Corporate Contracting (or "The Economics of Boilerplate"), 83 VA. L. REV. 713 (1997), and Michael Klausner, Corporations, Corporate Law, and Networks of Contracts, 81 VA. L. REV. 757 (1995).

104. A promise to pay can be inserted into the preferred stock contract in addition to dividend priority. The promise is not of the same order, however, as the promise to pay debt. Since dividends cannot be paid where debt is outstanding in distress situations, the promise is inherently conditional. 
when the firm possesses free cash flow, the problem presupposes that the preferred lack control or influence in the boardroom.

a. Vulnerability: Preferred Absent Control or Shared Control. The facts of Equity-Linked Investors, L.P. v. Adams, ${ }^{105}$ the leading case deciding a dispute respecting preferred stock issued to a venture capital investor, provide a more particular description of the problem.

This sad story starts in the portfolio company's fifth year. Called Genta Inc., it had successfully completed startup and gone public. At the time of its IPO, Genta sold a second round batch of preferred, $\$ 30$ million worth, to a group of venture capitalists $(V C)$. The preferred was at the weak end of the contract protection range $-V C$ neither controlled nor shared control in the boardroom and did not hold a voting majority of the shares. ${ }^{106}$

Genta needed the capital to operationalize a cluster of intellectual property rights in genetic research. Three years later, in mid-1996, nothing operational had come up. A second operating division of the company was at work on an application but had yet to produce a positive cash flow. A third division had a small biopharmaceutical manufacturing operation with a positive cash flow. Despite these efforts, Genta was running out of cash. Indeed, the company as a whole had consumed $\$ 100$ million over eight years without returning a dollar. Dr. Thomas Adams (the $E$ ) was the CEO.

$E$ was determined to stay in control and buy more time. Since $V C$ had refused to invest further capital, investment bankers were hired to scare up new financing, equity or debt. Meanwhile, $V C$ pressured $E$ and his board of directors to sell off the firm's assets and distribute the lion's share of the proceeds to it. $E$ resisted. Unfortunately for $V C$, its contracts gave it no rights with which to force the issue. Genta had a near-term duty to redeem the preferred, but Genta could satisfy the duty with either cash or common stock. Since Genta had no cash, the redemption had to be in stock. Genta's problem was that as the redemption date approached, Nasdaq was initiating delisting proceedings because Genta no longer met minimum standards. Meanwhile, delisting was classified in the preferred stock contract as a "fundamental change" that triggered a cash redemption right. This put $E$ in a race against the clock. He had to find new financing and stabilize the firm's cash flow position before Nasdaq delisted the common stock, triggering the cash redemption. ${ }^{107}$ Since there was no way to finance a cash redemption, triggering meant a defensive

105. 705 A.2d 1040 (Del. Ch. 1997).

106. Id. at 1043-44.

107. Id. at 1045-52. 
bankruptcy filing to prevent the preferred from executing a judgment against all of the assets of the company. ${ }^{108}$

$E$ and Genta managed to win the race by a nose, stalling Nasdaq by begging for more time even as they closed a desperation financing with a firm called Aries, run by a Dr. Rosenwald. In exchange for a $\$ 3$ million loan, secured by Genta's assets, Genta gave Aries control of the board along with a fistful of warrants and conversion rights that carried majority voting control of the firm. Aries promised to use its best efforts to raise more capital; if it did not raise another $\$ 3.5$ million in six months, it would lose its right to nominate a majority of the Genta board. $E$ 's continued status was not clear. Apparently, Aries could designate its own CEO. $V C$ protested the deal, offering to advance a slightly larger amount of cash on the same terms. The Genta board refused the offer. Its contract having failed it, $V C$ decided to seek judicial protection in Delaware, Genta's state of incorporation. ${ }^{109}$

For $V C$ to have to go to court was to admit contract failure. Yet $V C$ 's contract followed the overall pattern predicted by the CTM having repayment of the senior security come due in the event of $\theta_{b}$. Here, by implication, $a^{*} \theta_{b}$ was not a new business plan for the going concern but the sale on a going concern basis of the firm's producing assets. More than crumbs off the table were at stake: Genta had one profitable division; Aries saw realizable assets worth at least $\$ 3$ million. Unfortunately, the delay in triggering the cash redemption right engineered by $E$ had a disastrous impact on the value of $V C$ 's interest. While $V C$ sat on its hands waiting for Nasdaq, the closing of the Aries loan gave Aries a priority interest to the proceeds of a liquidation of the producing assets. In the terms of the CTM, the contingent control transfer provision in this venture capital contract relied on an $s$ - Nasdaq delisting - that was manipulable in addition to being observable and verifiable. The delay in triggering put $V C$ in the position Eastern Airlines' bondholders had experienced a decade earlier - watching the transfer of their collateral to parties providing new capital as the firm's insiders speculated on a low-probability turnaround.

Any number of contracting strategies could have averted this problem. For example, an old-fashioned business covenant prohibiting the incurrence of new debt and triggering a cash redemption right would have chilled the Aries deal. In the alternative, the drafter might have expanded the menu of redemption triggers, keying the additional entries to negative information generated by Genta, such as cash flow or other financial measures or production targets. This returns us to

108. Id. at 1044 n.6.

109. Id. at 1050-52. 
the problem of identifying an appropriate $s$. Like the CTM's $s$, real world proxies tend to be imperfect. Indeed, as recent events surrounding the Enron bankruptcy have reminded us, many accounting figures used as contracting signals are manipulable. The solution to that problem lies in the provision of a long menu of triggers. But this can present its own operational problems, for triggers can go off too early or too late. Of course, an early triggering invites waiver by $V C$ and attendant renegotiation. But to the extent $E$ has bargaining power, the waiver argument will not be ex ante persuasive. In sum, the evolution of an effective set of triggers can take experience across generations of contracts. Meanwhile, an outside, noncontrolling $V C$ is always better off with than without one.

In the alternative, the preferred stock contract might have granted $V C$ control of the board of directors or a seat on the board with a chance to influence a neutral outside director. As we have seen, most venture capital contracts do bestow one or the other. With $V C$ in charge in the boardroom, Genta would have been steered toward orderly liquidation, no last-ditch financing would have been in the works, and no one would have bothered to delay Nasdaq delisting. With board control, investment and dividend policy no longer presents a problem from preferred's point of view. In some situations the $V C$ control solution will be problematic from an efficiency point of view, of course - this is a fundamental insight of the CTM. How likely is $V C$ control to mean inefficient choices? Certainly, in this context the debt-like characteristics of preferred participation should not contribute to this risk of suboptimal decisionmaking by causing the preferred to err on the side of risk aversion in framing an investment plan. If we put $E$ 's private benefits to one side, the conversion privilege aligns the long-term interests of the preferred and common in $\theta_{g}$ states. Interests diverge in $\theta_{b}$ states, where, as in Adams, $V C$ will be ready to give up and liquidate earlier than will $E$. Here both the CTM and the facts in Adams suggest that $V C$ control in $\theta_{b}$ states is likely to be a superior arrangement.

b. Legal Framework. Equity-Linked Investors v. Adams provides a good example of the judicial treatment accorded to preferred claims. The regime of judicial enforcement bears directly on the burden facing the drafter of the preferred stock contract. Unless courts provide a protective backstop against opportunistic transfers of value and stripping of rights, any contract package falling short of giving the preferred outright boardroom control implies a risk of opportunism unless its drafter manages to specify all salient contingencies.

Unfortunately, Delaware law holds out no serious promise of fiduciary protection against issuer opportunism for preferred stockholders. Under Delaware law, the preferred share the role of fiduciary beneficiary with the common only with respect to elements of preferred participation constituting an equity participation identical 
to that of the common. Accordingly, the preferred have a cause of action along with the common where management engages in selfdealing transactions or negligently mismanages the firm. In contrast, where a preferred claim arises from rights and preferences not shared with the common, the Delaware courts characterize the claim as contractual rather than fiduciary. ${ }^{110}$ They then read the contract narrowly. ${ }^{111}$

Accordingly, counsel for $V C$ in Adams needed to construct a claim that did not derive from the liquidation preference and instead went to the stock's core equity participation. It cleverly did this by making reference to the Delaware fiduciary rules constraining management defensive tactics against hostile takeovers. More particularly, it attacked the Aries deal as sale of control within Revlon, Inc. $v$. MacAndrews \& Forbes Holdings, Inc. ${ }^{112}$ presenting $V C$ in the capacity of an equityholder (rather than in the capacity of a senior securityholder), protesting management's failure to act to maximize the value of the firm in connection with a control transfer. If the deal was within Revlon, the $V C$ argued, then the Genta board had a duty to maximize the value received in exchange for the control transfer. By refusing $V C$ 's better offer, it breached the duty.

The Delaware Chancery court rejected the theory, despite a significant counterfactual acknowledgment. It admitted that in an open auction for the company held at the time of the Aries deal, $V C$ 's interest in accessing the proceeds of liquidation would have caused its bid to be the highest:

Assume, for example, that the present value of the firm's prospects as a going concern would be only $\$ 9$ million (net), which is also its liquidation value. Assume that in an open bidding contest, a well informed bidder will offer the company something less than 3 million for a $51 \%$ interest (i.e., $\$ 9 \mathrm{~mm}+\$ 3 \mathrm{~mm}=\$ 12 \mathrm{~mm}$ divided by $2=\$ 6 \mathrm{~mm}$; but since in liquidation the common stock would be worthless, the bidder would be unlikely to bid the maximum $\$ 6 \mathrm{~mm}$ value on these assumptions). Assume such a $\$ 3 \mathrm{~mm}$ bid would permit the common stock some further opportunity to see a payoff in the company labs and in the marketplace. Now assume that a bidding contest occurs in which the preferred takes part. What will probably happen? The preferred's aim might be simply to liquidate the company and take all of the net proceeds and apply it to its preference. This will prevent its exploitation by the common and cut its

110. See Jedwab v. MGM Grand Hotels, Inc., 509 A.2d 584 (Del. Ch. 1986); Dalton v. Am. Inv. Co., 490 A.2d 574 (Del. Ch. 1985).

111. Kaiser Aluminum Corp. v. Matheson, 681 A.2d 392 (Del. 1996) (refusing to resort to extrinsic evidence in interpreting preferred stock contract and instead employing the maxim of interpretation contra proferentum); Warner Communications Inc. v. Cris-Craft Indus., Inc., 83 A.2d 962 (Del. Ch. 1989) (interpreting language literally protecting preferred stockholders against them).

112. 506 A.2d 173 (Del. 1986). 
losses. To accomplish that goal, the preferred could easily pay in an auction up to $\$ 21$ million ( $\$ 30$ million liquidation preference minus present net liquidation value) because that amount would go into the company's treasury but could be immediately restored to the preferred when it exercised its voting power to cause the liquidation of the firm. ${ }^{113}$

But the competitive bidding scenario did not determine the result in the court's fiduciary analysis. The question for purposes of fiduciary law, it reasoned, was not whether the board of directors had maximized the value of the assets or of the firm. The fiduciary regime addressed only the board's good faith in pursuit of value for the common stock interest:

What is clear is that the Genta board was striving to maximize the possibility of the common stock participating in some "upside" benefit from the commercial development of the company's intellectual properties. It is clear too that the course it took to do that arguably was superior to an alternative in which the preferred acquired control, because the preferred had a financial incentive to liquidate the firm immediately, thus depriving the common of any current value. Thus, unlike two competing cash transactions or transaction in which widely traded securities are offered, the alternatives that plaintiff poses are rich with legitimate, indeed unavoidable, occasions for the exercise of good faith business judgment.

[This is not] a situation in which, from the common stock's perspective, "there is no tomorrow," and the board ought not be recognized as having discretion to prefer what it sees as a "longer term value" over a higher present value. The court would have no basis to conclude that the immediate value of the common would in fact be greater had an alternative of the kind presented by the preferred somehow been put in place.... ${ }^{114}$

In effect, the Delaware court here declined to use fiduciary law as the basis for implying a maximizing control transfer mechanism. In so doing it acted in accord with the structure of American fiduciary law. The law's charge to the corporate board to work diligently and loyally to enhance value is phrased in terms of the overall "firm" only in general articulations ${ }^{115}$ or in cases where the effect is to strengthen management's hand against a hostile tender offer for the common

113. Equity-Linked Investors, L.P. v. Adams, 705 A.2d 1040, 1057 (Del. Ch. 1997).

114. Id. at 1058-59.

115. See, e.g., ALI PRINCIPLES OF CORPORATE GOVERNANCE: ANALYSIS AND RECOMMENDATIONS $\$ 2.01$ (1994). 
stock. ${ }^{116}$ Where board decisions implicate conflicting interests of classes of equity securities (or conflicting interests of debt and equity securities), and management acts to advance the interests of the common stockholders, the value to be maximized becomes the value of the common stock.

This alignment between fiduciary obligation and the common stock's interest reflects first-generation agency theory, which held that the residual interest holder has the value-maximizing incentive in all going-concern situations outside the vicinity of insolvency. ${ }^{117}$ The CTM's primary lesson for the law is that this assumption is not nearly as safe as the corporate law literature seems to think. ${ }^{118}$

The legal primacy of the common stock interest also reflects institutional concerns. In a hypothetical alternative regime, the board is charged with maximizing firm value whatever the allocational consequences among classes of securityholders. ${ }^{119}$ Information asymmetries between the boardroom and the courtroom make intervention to enforce such an open-ended maximization duty impracticable. Courts do not have the technical wherewithal to review corporate boards on the substance of their business decisions. They prefer to limit inspection to process contexts, which implicate facts and factors more immediately intelligible and amenable to judicial review. ${ }^{120}$ The courts also accord the board a wide zone of discretion in which to resolve pie-slicing disputes among different classes of securityholder. For example, had the Genta board decided in good faith and upon due diligence that the game was up - that the Aries deal was one-sided and unlikely to lead to a turnaround and to put the firm to the preferred in accord with their contract - the common

116. The reference is to corporate law's constituency statutes. CONN. GEN. STAT. ANN. § 33-756(d) (West 1997); IND. CODE ANN. § 23-1-35-1(f) (West Supp. 2001); N.Y. BUS. CORP. LAW $\$$ 717(b) (McKinney Supp. 2001-02).

117. Jonathan R. Macey, An Economic Analysis of the Various Rationales for Making Shareholders the Exclusive Beneficiaries of Corporate Fiduciary Duties, 21 STETSON L. REV. 23 (1991). Distress situations are the exception. There the equity has a number of perverse incentives that can lead to reduction in the value of the firm's producing assets. See Credit Lyonnais Bank Nederland, N.V. v. Pathe Communications Co., 1991 WL 277613, at *33 \& n.55 (Del. Ch. Dec. 30, 1991).

118. For a contrasting economic approach to the same endpoint, see Thomas A. Smith, The Efficient Norm for Corporate Law: A Neotraditional Interpretation of Fiduciary Duty, 98 MICH. L. REV. 214 (1999).

119. Morey W. McDaniel, Bondholders and Stockholders, 13 J. CORP. L. 205 (1998); Morey W. McDaniel, Bondholders and Corporate Governance, 41 BUS. LAW 413 (1986).

120. See Paramount Communications, Inc. v. QVC Network Inc., 637 A.2d 34 (Del. 1993), where the Delaware Supreme Court moves Revlon review away from business substance in the direction of process review. Under $Q V C$ the question is less whether the board maximizes value than whether the board informed itself of available alternative courses of action respecting value maximization. 
stockholders would have been hard pressed to articulate an action for breach of fiduciary duty. ${ }^{121}$

The foregoing justification of the ruling in Equity-Linked Investors, L.P. v. Adams, however, leaves open some problems. Since Genta was in distress, governance in the common's interest was not presumptively efficient. Furthermore, the court could have ruled for the preferred without instituting an unworkable fiduciary regime. Genta's delaying actions respecting Nasdaq delisting easily could have been characterized as a breach of the contractual duty to act in good faith. The contract accorded the preferred a right of redemption in the event of delisting; but for the board's intervention with Nasdaq, the delisting would have occurred, perfecting the right. ${ }^{122}$ Since the action frustrated the exercise of the right, it arguably violated the contract law good faith duty in its narrower articulation, under which the duty protects performance of the contract's explicit terms only and implicates no broad, fiduciary-like duty of self-abnegation. The foregoing characterization of the Adams situation is well within the narrow statement of the duty, a formulation held applicable to senior securities in Delaware cases. ${ }^{123}$

It should be emphasized that the good faith rule referenced here is a special rule that applies only to debt and preferred stock contracts. It bears only the most tenuous familial relationship with the duty of good faith described in the Restatement $2 d$ and taught in first year courses. The Restatement's good faith standard invites aggressive application to protect contract parties in positions of disadvantage. It constrains opportunism to protect expectations. ${ }^{124} \mathrm{~A}$ variant of this standard applies when an interpreting judge concludes that the contract contains no term dictating a result on the facts of the case. In such an "omitted term" case, the decisionmaker is invited to interpolate a term following from community standards of fairness. Once again aggressive intervention is invited. ${ }^{125}$ Two decades ago, plaintiffs invited courts to apply these precepts aggressively to protect holders of bonds and preferred stock. Instead, beginning with the famous case of Broad

121. Compare Orban v. Field, 1997 WL 153831 (Del. Ch. Apr. 1, 1997), a venture capital case in which the court sustains the board's action to wipe out a common stockholder in favor of preferred classes holding a majority of the votes.

122. Had the Genta board taken no steps to delay, delisting would have occurred in early December 1996. 705 A.2d 1040, 1047 (1997). Delaying tactics caused delisting to be delayed until February 4, 1997; the Genta board approved the Aries deal on January 28, 1997. Id. at 1051-52 \& n.34.

123. Simons v. Cogan, 542 A.2d 785 (Del. Ch. 1987); Katz v. Oak Indus. Inc., 508 A.2d 873 (Del. Ch. 1986).

124. RESTATEMENT (SECOND) OF CONTRACTS $\S 205 \mathrm{cmt}$. a (1981).

125. Id. $\$ 204 \mathrm{cmt}$. d. 
v. Rockwell International, ${ }^{126}$ the courts invented a restrictive variant, pursuant to which the good faith duty is not breached unless an articulated contract right has been violated. In most situations, this bond and preferred good faith rule negates the Restatement's good faith regime. Good faith is a backstop duty intended to come to bear to protect parties who do not have specific contract provisions to protect them. In the vast majority of cases, to require a contract term first is to say "no good faith duty." But there remains a subset of cases in which the bond and preferred good faith variant assists a victim of opportunism. Adams is in this subset. ${ }^{127}$

Unfortunately for $V C$ this is a small subset. The drafting burden on preferred remains so onerous as to make the little good faith protection held out in the cases more theoretical than real. The judges enforcing the terms of preferred stock contracts give the benefit of any doubts to the common. Part of the burden stems from the fact that in Delaware corporate politics often matter more than statements of doctrine. Corporate politics have not historically favored preferred claims because managers, who decide where to charter the firm, tend to be the actors with political influence. Accordingly, contingencies must be predicted with prescience and provided for in painstaking detail if the preferred's expectations are not to be frustrated.

Is this an efficient approach? The law of preferred stock thereby tracks the law and economics that refuses implied-in-fact and impliedin-law protections to corporate participants on the ground that in the long run forcing them to negotiate contracts leads to efficient results. But, as we have seen, ${ }^{128}$ this rationale is questionable. The complete contingent claims contract that the law thus demands as a vehicle for protecting preferred in the absence of boardroom control arguably is an economic impossibility. Preferred stock contracts traverse a considerable expanse of noncontractible territory. Of course, we also have seen that noncontractibility is not an absolute - the CTM, for example, designs a contract term that indirectly steers the parties toward an optimal solution of a noncontractible problem. But this also is exactly what the parties did in Adams, drafting a redemption provision based on Nasdaq delisting. It is true that $V C$ in Adams could have extracted a further explicit provision, one to the effect that $E$ would not actively seek to delay Nasdaq delisting. At this point, however, the forced contracting norm arguably has led us to an absurd

126. 642 F.2d 929, 957 (5th Cir. 1981) (en banc), cert. denied, 454 U.S. 965 (1981); see also Metro. Life Ins. Co. v. RJR Nabisco, Inc., 716 F. Supp. 1504 (S.D.N.Y. 1989).

127. For a second example, see HB Korenvaes Investments, L.P. v. Marriott Corp., 1993 WL 257422 (Del. Ch. Jul. 1, 1993) (showing that antidilution provisions governing an issue of convertible preferred can fail on some fact patterns, requiring intervention under the good faith rule).

128. See supra text accompanying notes $34-35$. 
result. After all, there is no such thing as a case where the drafter of a specific contract term could not have been even more specific.

The resulting message is disturbing: contractual specifications designed to protect preferred are intrinsically unreliable because reviewing courts welcome the opening of loopholes on behalf of the common stock. But for $V C$ the upshot is clear: the only reliable contracting course is to take boardroom control, full or shared. Such a narrowing of the menu of meaningful contractual choices cannot possibly be efficient.

\section{Control at the Shareholders' Meeting}

In the usual corporate power allocation, the board of directors manages the business and the shareholders elect the board. ${ }^{129}$ Shareholder approval also is needed for charter amendments, many mergers, sales of all or substantially all assets, and liquidations. ${ }^{130}$ Preferred stockholders also run into difficulties with respect to exercises of this shareholder legislative function.

To see why, consider a stylized retelling of the facts of Bove $v$. Community Hotel Corp. ${ }^{131}$ This case concerned a corporation with an issue of preferred on which no dividends had been paid for twentyfour years. The face amount of cumulated dividend arrearages was greater than the going concern value of the entire equity of the firm. The board of directors determined to eliminate the arrearages, ostensibly to make the firm a more attractive vehicle for debt financing.

During the first half of the twentieth century, boards in this position effected elimination of accumulated arrearages by engineering direct amendments of their firms' charters. A conceptual anomaly made this possible. The "preferred stock contract," unlike a contract governing corporate debt, is a part of the firm's charter. The charter, in turn, is subject to a statutory process directive respecting the power to amend. In the early twentieth century, most state corporate codes provided that a simple majority vote of all outstanding shares was sufficient to approve a charter amendment. Literally applied, this meant that where (a) an issue of preferred stock did not carry a majority of the votes of all issues of stock, and (b) the preferred issue had been created without a special charter term

129. DEL. CODE ANN. tit. $8, \S 141$ (a) (2001).

130. DEL. CODE ANN. tit. $8, \S \S 242,251,271,275$ (2001).

131. 249 A.2d 89 (R.I. 1969). In the actual case, direct amendment of the preferred stock contract required a $100 \%$ approval by the preferred and the merger required a class vote of the preferred. The retelling in the text substitutes the scenario that would have followed under today's Delaware statute. For a more recent example, see Elliott Assocs., L.P. v. Avatex Corp., 715 A.2d 843 (Del. 1998). 
requiring a separate vote of the preferred as a class to approve charter amendments implicating its interests, the rights and preferences of the preferred were subject to ex post stripping for the benefit of the common through use of its charter amendment power. This was seen as unfair, and many state courts invalidated such actions on a constitutional property rights theory. But that judicial theory became moribund. ${ }^{132}$

In response, state legislatures adjusted state corporate codes, including Delaware's, so as to afford the preferred a process protection. A majority vote of a given class of stockholders would be required whenever a charter amendment impaired that classes' contract rights. ${ }^{133}$ The preferred issuer in Bove, however, found a way to avoid that preferred class vote. Its board set up a shell, wholly owned subsidiary and engineered the merger of the issuer corporation into the shell subsidiary. Under the "merger agreement" between the two corporations, the common stock of the surviving corporation would be issued to both the common and the preferred of the issuer firm in proportions therein specified. Under the specification, the underwater common came away with a slice of firm value. The "merger agreement" thus had the effect of stripping value from the rights of the preferred specified in the charter. Here the managers in Bove exploited a second legal anomaly: in a merger the charter of the transferor corporation is replaced by the charter of the surviving corporation. A merger, accordingly, is a charter-amending event.

The merger in Bove had to be submitted for shareholder approval. But the state code required a class vote of the preferred in the case of a charter amendment injurious to the preferred, but required only a vote of all the shareholders as one class for a merger. In effect, the sole purpose of the merger into the shell subsidiary was to provide a vehicle for recapitalizing the firm's equity and eliminating the preferred arrearages without a class vote of the preferred being required. Yet the state court sustained the merger. That the merger was engineered solely for the purpose of eliminating the arrearages and that the statute provided for a class vote (and veto) in its instructions respecting the direct means to the end was neither here nor there. Under corporate law's "doctrine of independent legal significance," first articulated in Delaware in a similar case, different sections of the corporate code are to be read literally and independently. A policy implication of one section does not provide a court a basis for implying a limitation on the utilization of another section. Accordingly, the provision for a class vote on changes

132. See supra text accompanying note 100 .

133. DEL. CODE ANN, tit. $8, \S 242$ (b)(2) (2001). Even with a class vote, publicly traded preferred has been known to approve right-stripping amendments. See, e.g., Bowman v. Armour \& Co., 160 N.E.2d 753 (Ill. 1959). 
injurious to the preferred's interest in the charter amendment section of the code does not imply a general rule that preferred may in no circumstances have its rights stripped absent a class vote. As a result, the merger section may be used to strip preferences from preferred because it literally does not provide for class vote even though preference stripping was the only purpose of the merger.

In general, state corporate codes are not interpreted to possess policy coherence. No embarrassment stems from the resulting interpretive anomalies. Instead, they are celebrated because they lend freedom of action to insiders.

Once again, the message for preferred holders is get a better contract. And indeed, preferred can contract around the Bove problem with a provision in the charter for a class vote in connection with mergers. ${ }^{134}$ But such provisions are rare in charter provisions governing publicly issued preferred. A study conducted in the late 1980 s of charters governing preferred issued by Delaware corporations and listed on the New York Stock Exchange found that only $14 \%$ required a class vote in respect of a merger. ${ }^{135}$ Many issuers have taken advantage of this failure to draft carefully, successfully structuring mergers that transfer value from the preferred to the common.

The Delaware courts have supported the issuers and their value transfers. They ruled in the touchstone case of Rothschild $v$. Liggett that preferred can be cashed out in a merger for substantially less than its liquidation preference, a "merger" not being "liquidation" even where the particular class of stock is being cashed out in the merger. ${ }^{136}$ Elsewhere, Delaware has sanctioned a merger where the managers of the transferor firm bargained down the consideration first offered for the preferred by the acquiring firm even as they bargained up the consideration on offer for the common. ${ }^{137}$ Finally, in Delaware the exercise of drafting a charter that actually provides for a class vote in a merger has proved to be a game played by secret rules. In Warner Communications Inc. $v$. Chris-Craft Industries, Inc., ${ }^{138}$ the court held that a provision requiring a two-thirds class vote to alter any preferences, rights, powers or privileges of the preferred did not operate in respect of a merger, even though the charter had a separate

134. Some states, such as New York, N.Y. BUS. CORP. LAw $\S 903(a)(2)(B)$ (McKinney Supp. 2002), provide for a class vote. Delaware does not. DEL. CODE ANN. tit. 8 , $\$ 251$ (2001).

135. Note, Arrearage Elimination and the Preferred Stock Contract: A Survey and a Proposal for Reform, 9 CARDOZO L. REV. 1335 (1988).

136. Rothschild Int'l Corp. v. Liggett Group, 474 A.2d 133 (Del. 1984).

137. Dalton v. Am. Inv. Co., 490 A.2d 574 (Del. Ch. 1985).

138. 583 A.2d 962 (Del. Ch. 1989). 
provision requiring a two-thirds class vote in respect of charter amendments. ${ }^{139}$

Preferred stockholders face a uniquely hostile interpretive environment. The charter competition phenomenon helps explain this atmosphere. Delaware's much vaunted responsiveness ${ }^{140}$ extends primarily to the corporate actors who make the decision respecting the state of incorporation. With publicly traded firms, those actors are the managers acting as agents for the common stock. When senior-junior securityholder interests conflict, the managers' interest usually lies with the juniors. As a result, the Delaware courts have for decades been ratifying senior-to-junior wealth transfers.

One might predict movement away from this blood sport respecting senior securities toward a more even-handed mediation respecting venture capital. In the world of corporate law as product, venture capital could amount to a submarket. $V C$ s are repeat players in a position to contest and indeed to direct the startups' choice of state of incorporation. Should a number of venture capital firms experience bad results in Delaware litigation, Delaware could suffer a negative reputational effect in the venture capital community. Of course, Delaware has run into reputational problems in the past. ${ }^{141}$ It has retained its market share despite these moments of friction because substantial costs and risks of entry inhibit the appearance of a state plausibly competing for the charters of large, mature firms. ${ }^{142}$ Entry might be easier for a competitor tailoring a legal regime for a venture capital submarket. On this analysis, the cavalier attitude displayed to the interests of $V C$ in Equity-Linked Investors $v$. Adams is surprising. But Delaware lawmakers are famous for trimming their sails upon becoming aware that actors in the capital markets disapprove of a ruling. We have already seen a gesture of solicitude to $V C s$ holding Delaware preferred. ${ }^{143}$ We very well may see more.

139. It should be noted that Delaware has since ruled that a provision for a class vote respecting "amendment ... by merger" did apply to a merger. But it did so only after the case was litigated to the state's supreme court. Elliott Assocs., L.P. v. Avatex Corp., 715 A.2d 843 (Del. 1998).

140. Roberta Romano, The Genius of AmERiCAn CoRPorate LAW 37-44 (1993).

141. The most famous case is the Delaware Supreme Court's sudden expansion of the duty of care to cover board approval of an arm's length merger in Smith v. Van Gorkom, 488 A.2d 858, 873-81 (Del. 1985). Insurance premiums rose substantially as a result and the legislature amended the Code to permit firms to opt out of the duty of care by charter amendment. See DEL. CoDE ANN. tit. 8, § 102(b)(7) (2001).

142. See William W. Bratton \& Joseph A. McCahery, Regulatory Competition, Regulatory Capture and Corporate Self-Regulation, 73 N.C. L. REV. 1861, 1894-95 (1995).

143. See Telcom-SNI Investors, L.L.C. v. Sorrento Networks, Inc., No. Civ. A. 19038NC, 2001 WL 1117505 (Del. Ch. Sept. 7, 2001) (enjoining an $E$ from violating a debt covenant and a provision requiring a preferred class vote to approve a new, prior, or equal class of preferred, holding that the contract meant what it said). 
Meanwhile, a preferred stockholder who does not control the board or possess a majority of the voting shares needs a carefully drafted, triple-riveted set of charter terms. Having gotten that, it will still need the best lawyer in town should any problems arise.

\section{B. Venture Capital Contracting Practice}

The preferred stock problem tends to arise on the intermediate downside - the issuer performs poorly but not so poorly as to trigger a bankruptcy filing. This particular stretch of downside territory occupies a relatively short segment on the range of contingencies addressed by venture capital contracts. Here wealth allocations, incentives, and decisionmaking power on $\theta_{g}$ scenarios are the primary contracting concern. These are addressed in the first instance by the terms of the conversion privilege attached to the preferred and the provision of registration rights facilitating later exit via the public trading markets. ${ }^{144}$ Concerns about the $E$ 's incentives also loom large on the upside. These are addressed by allocating $E$ 's equity interest in the firm's growth in the form of stock options that vest over time, diminishing any temptation to abandon the project prior to the IPO phase and, in the vast majority of cases where $E$ does not have full boardroom control, importing a high-powered incentive to remain in the good graces of $V C$ and the outside director or directors. ${ }^{145}$ Provision for mandatory conversion of venture capital preferred in the event of a qualifying IPO ${ }^{146}$ also aligns incentives by constraining the form of $V C$ 's upside payoff ${ }^{147}$ and, in cases where $V C$ has shared voting control, by opening a path to an upside control transfer to $E$. More generally, the contract's primary job is to align incentives toward success and provide for gain sharing and eventual access to liquidity for $V C$.

Venture capital contracts treat the deepest downside scenarios by shaping priorities. A startup firm creating no value and running out of capital goes into bankruptcy, probably to be liquidated once there. This risk is intrinsic to venture capital investment. Venture capital

144. See Black \& Gilson, supra note 17, at 260-61, 264; Edward B. Rock, Greenhorns, Yankees and Cosmopolitans: Venture Capital, IPOs, Foreign Firms \& U.S. Markets, 2 THEORETICAL INQUIRES IN LAW 711 (2001). For a theoretical model showing how the conversion feature aligns the incentives of the entrepreneur with those of the venture capitalist, see Francesca Cornelli \& Oved Yasha, Stage Financing and the Role of Convertible Debt (SSRN Elec. Paper Coll. No. 48581, 1997), at http://papers.ssrn.com/abstract=48581.

145. See Kaplan \& Strömberg, supra note 12 (working paper at 30 \& n.10); see also Oliver Hart \& John Moore, A Theory of Debt Based on the Inalienability of Human Capital, 109 Q.J. ECON. 841 (1994).

146. The IPO must pass quality tests keyed to the stock price, the amount of proceeds or the resulting market capitalization. Kaplan \& Strömberg, supra note 12 (working paper at 21).

147. Black \& Gilson, supra note 17 , at 261. 
firms moderate it by staging $E$ 's draw downs of capital, ${ }^{148}$ by diversifying their portfolios of investments in startup firms, by syndicating investments in particular firms, and by closely monitoring their positions. ${ }^{149}$ When a particular investment does turn out to be a complete failure, the contract structures priorities to allocate any crumbs left on the table to $V C{ }^{150}$ But these often do not amount to much.

Suboptimal or mediocre performance short of complete failure presents a less tractable problem, although not so much so with venture capital portfolio companies as with mature preferred issuers. With startup firms, indifferent results can lead directly to the disaster scenario. Outside capital is needed for survival and poor results mean that capital is cut off, given staged investment. In contrast, poorly performing mature firms can survive for years, with the option of omitting to pay dividends on preferred being a factor assisting in that survival. There are also drastic differences in duration between senior securities issued by mature firms and venture capital preferred. The preferred that concerned Graham and Dodd was issued in the early and mid-twentieth century, before the inflation of the 1960s and 1970s. In those days, preferred stocks often had no mandatory redemption schedule and thus, like common, had an indefinite duration. ${ }^{151}$ Venture capital preferred tends to take an intermediate term, with a duration of four to six years. ${ }^{152}$ When the time is up, redemption rights become exercisable, and the mediocre performer still limping along either finds replacement capital or becomes a disaster case.

Mediocrity between startup and year five is a problem less easily treated through advance specification. When value lies on the table unmaximized, by definition a governance problem exists, although not necessarily a verifiable one. As we have seen, the solution turns on intervention by $V C$ to replace $E$ as $C E O$, and venture capital contracts in most cases deal with this problem either by vesting boardroom control in $V C$, or by making sure that boardroom control remains contestable. Given the latter situation, and a neutral outside director with a deciding vote, opportunistic stripping of preferred rights and preferences seems unlikely. Even if such a resolution passes in the boardroom, the $V C$ is safe so long as it possesses voting control at shareholders' meetings. Kaplan and Strömberg's numbers on voting control thus show us that the preferred stock problem is solved in

148. Sahlman, supra note 7 , at 507 .

149. GOMPERS \& LERNER, supra note 71, at 139-202.

150. Some venture capital firms have members who specialize in this downside cleanup function. I owe this point to Professor Marcus Cole.

151. Morey McDaniel, Sinking Fund Preferred Stock, 13 FIN. MGT. 45-52 (Spring 1984).

152. Kaplan \& Strömberg, supra note 12. 
$70.8 \%$ of cases with no vesting of $E$ equity and $55.8 \%$ with full vesting. Since the preferred stock problem tends to arise in $\theta_{b}$ states and vesting is unlikely to be full in those states, stripping of $V C$ preferences and other downside opportunism turns out to be a possibility in about one-third of the cases. But it also should be noted that mergers and acquisitions occur in $\theta_{g}$ states as well. So the possibility of stripping still exists in the $45 \%$ of full vesting cases where $V C$ does not have voting control.

To what extent are these minority-vote $V C$ s threatened by opportunism from majority vote $E$ s due to their status as preferred holders? The primary limitations on exposure are built into the transactions' overall economic structure. These deals have a limited, intermediate term, with $E$ being required to raise cash to redeem the preferred in $\theta_{b}$ states. Prior to liquidation, boardroom control remains contestable in $58 \%$ of the cases where the $V C$ does not have voting control. So the window for opportunism opens in only a minority of cases and stays open for only a short period. Of course, Adams shows how a majority-vote $E$ can strip value even during this short period.

The degree to which value and rights can be stripped in this minority of cases depends on fine points of contracting practice. The literature shows that standard venture capital preferred contracts provide for class votes in respect of adverse charter amendments, increases in the number of authorized shares, and the authorization of preferred classes of higher priority. ${ }^{153}$ Mergers are treated separately under a one-size-fits-all term. A merger is treated as a liquidation, triggering a right to redeem the preferred if the "stockholders of the Company immediately prior to [closing of the transaction] own less than $50 \%$ of the Company's voting power" thereafter. If the merger is treated as a liquidation, a class vote also is provided for. If the merger is not treated as a liquidation, no class vote is provided for. ${ }^{154}$

This one-size-fits-all term is substantially effective, even as it falls a step short of perfection. The term manifestly is designed to overrule Rothschild $v$. Liggett's ruling that a cash-out merger is not a liquidation. ${ }^{155}$ Where all of the shares of the transferor firm in the merger are cashed out, the term manifestly achieves its intended purpose. The preferred liquidation rights become immediately

153. See Dauchy, supra note 75 , at 315 ; see also Hank Barry, Negotiating Preliminary Financing, in 20TH ANNUAL INSTITUTE ON COMPUTER LAW 849, 860 (PLI Patents, Copyright, Trademarks, and Literary Property, Course Handbook Series No. 590, 2000).

154. Ellen B. Corenswet et al., Venture Capital Considerations in Mergers and Acquisitions, in HANDLING MERGERS \& ACQUisitions IN High-TECH AND EMERGING Growth EnVIronments 1999, at 655, 661-62 (PLI Corp. L. \& Prac., Course Handbook Series No. 1122, 1999); Dauchy, supra note 75, at 317; Richard R. Plumridge, Typical Venture Capital Transaction Documents, in PRIVATE PLACEMENTS 2001, at 817, 856-57 (PLI Corp. L. \& Prac., Course Handbook Series No. 1239, 2001).

155. See supra text accompanying note 136. 
exercisable, and the preferred gets a class vote that allows it to veto the merger. But the preferred with a minority of the overall shares will not be protected under this provision in all cases. Here are three examples.

(a) $X$ Co. has 6,000 shares of common outstanding held by $E$ amounting to $60 \%$ of its total shares (6,000 total); 4,000 shares $(40 \%)$ of preferred are held by $V C$. The liquidation value of the preferred is $\$ 100$ (or $\$ 400,000$ ). $X$ Co.'s total value is $\$ 500,000$. Acquiring firm $A$ $C o$., which is controlled by the third director of $X C o$., organizes a shell acquisition subsidiary, $A S u b$, which issues to $A C o$. 5,000 common shares. $A$ Sub merges into $X$ Co. pursuant to a merger agreement providing that 5,000 of the $6,000 X \mathrm{Co}$. common shares are to be converted into $\$ 40$ cash. The other $1,000 X \mathrm{Co}$. common shares are left to ride, as are the preferred shares. The shares of $A S u b$ are converted into 5,000 common shares of $X \mathrm{Co}$. Simultaneously with the closing of the merger, $X \mathrm{Co}$. borrows the $\$ 200,000$ to be paid to its common stock in the merger, giving the lender a note and mortgage on $X$ Co.'s property. $A C o$. also takes a long-term option to buy the remaining 1,000 shares of $X$ Co. for $\$ 20$.

In this deal, when the shooting stops, the acquirer has bought exactly $50 \%$ of the target common, thereby avoiding triggering liquidation. The preferred has no incentive to convert to common prior to the closing since the value of the $X \mathrm{Co}$. into which it would convert is less than its liquidation preference. The preferred is better off holding to maturity. $A C o$. is doing a leveraged speculation on an increase in $X$ Co.'s equity value, using the assets of $X C o$. as a borrowing base and putting in no significant capital of its own. It must delay purchase of the remaining $10 \%$ of $X \mathrm{Co}$. to avoid triggering liquidation and a class vote. But it can bide its time on that purchase - the remaining common has no incentive to defect to the side of the $V C$ in internal votes. As in Adams, the $V C$ cannot block the borrowing unless a debt covenant is included in the preferred stock contract. Without a debt covenant, and assuming both liquidation at maturity and that $X C o$. still is worth only $\$ 500,000, V C$ now receives $\$ 300,000$ rather than $\$ 400,000$. Its equity upside rides largely unaffected.

The convoluted structure of the hypothesized merger shows that the standard venture preferred merger provision is effective across a broad range of merger and acquisition territory: normally, the acquiring firm wants at least $51 \%$ of the voting equity. But the hypothetical also shows that a loophole can be opened in a pinch. With value on the table to be stripped, that cannot be considered an event with a de minimis probability. As to the use of business covenants which would block the borrowing in the foregoing hypothetical, the literature signals variations in practice. Some lawyers 
suggest that business covenants should be included in the "investor rights agreement" usually entered into between $V C$ and $E .{ }^{156}$ Other descriptions of standard deal documentation make no mention of business covenants. The Kaplan and Strömberg numbers indirectly suggest that business covenants are the exception rather than the rule. They report that $20 \%$ of their cases involved contract provisions contingent on subsequent financial performance, but none of the provisions they describe are negative covenants. ${ }^{157}$

(b) The firm this time is $Y C o$., with common held by $E$ amounting to $60 \%$ of the shares $(6,000$ total $)$ and the preferred held by $V C 40 \%$ $(4,000$ total). The liquidation value of the preferred is $\$ 100$ (or $\$ 400,000)$. The total value of $Y C o$. is $\$ 640,000$. Y Co. merges into $B$ Co., which has 6000 shares of common outstanding prior to the merger. The total merger consideration is $\$ 640,000$. The merger treats $Y$ Co.'s two classes of stock differentially so far as concerns consideration. Each share of common gets one share of the surviving corporation worth $\$ 80$ per share if no preferred is converted prior to the merger; the stock is worth $\$ 64$ if all of the preferred is converted prior to the merger. The preferred gets cash worth $\$ 40$ per share. Here, since more than $50 \%$ of the stock of the surviving corporation is held by $Y C o$. holders, the liquidation/class vote provision is not triggered. Given a conversion privilege, the preferred can convert into common on a one-to-one basis prior to the merger closing. If all of the preferred converts 10,000 shares will share the merger consideration, which will thus be worth $\$ 64$ per share. If the merger were a liquidation, the preferred would have a right to receive $\$ 100$ per share in cash.

Once again, the scenario is convoluted. This merger averts triggering the clause only because the acquiring corporation has the same number of common shares outstanding as the target. Postmerger, $Y C o$. common and $B C o$. common each hold 6,000 shares. If $V C$ converts, former $Y C o$. investors hold 10,000 of 16,000 . Since, by hypothesis, the $Y \mathrm{Co}$. shares are held by a handful of actors, control in effect passes to $Y C o$. actors, something the firm in $B C o$.'s position is unlikely to countenance. It is more likely in the case of stock-for-stock deal like this that the $B C o$. holders end up with a clear majority. That

156. Plumridge, supra note 154, at 647; Kathryn K. Lindauer, Critical Issues in Negotiating Venture Capital for the Software Development Company, in 19TH ANNUAL INSTITUTE ON COMPUTER LAW 799, 321-22 (PLI Patents, Copyright, Trademarks, and Literary Property, Course Handbook Series No. 547, 1999).

157. Kaplan \& Strömberg, supra note 12 (working paper at $19 \&$ tbl.6). It is entirely possible that Kaplan and Strömberg were not looking to see if the investor rights agreements in their transactions contained business covenants. It also is possible to draft negative covenants that do not turn on future financial performance figures. One can, for example, completely forbid short term borrowing and funded debt without regulating it by reference to a balance sheet test. 
case, of course, triggers the clause. Alternatively, $B C o$. pays in cash, debt securities, nonvoting common, or a mix of any of those with voting stock. In all of those cases, the deal in all probability triggers the clause.

(c) One glaring loophole remains: the fact pattern of the Bove case described above. This time the firm is $Z C o$. It has 6000 shares of common outstanding held by $E$ amounting to $60 \%$ of its total shares $(6,000$ total); 4,000 shares $(40 \%)$ of preferred are held by $V C$. The liquidation value of the preferred is $\$ 100$ (or $\$ 400,000$ ); the dividends are cumulative and $\$ 100,000$ in arrears. $Z$ Co.'s total value is $\$ 500,000$. $Z$ Co. creates a shell, wholly owned subsidiary, EZ Corp., and merges into it. Pursuant to the merger agreement (drafted by $E$ ), the preferred and common of $Z C o$. are to receive common of $E Z$ Corp., 5,001 shares to the common and 4,999 shares to the preferred. Since the voting stock of the surviving corporation is held by the same holders as the voting stock of the transferor corporation, the clause is not triggered and $V C$ cannot block the deal under the contract. $V C$ will have a plausible case for breach of fiduciary duty and will be able to bring an appraisal proceeding pursuant to which it will be able to claim the value of its shares in cash. Both lawsuits are powerful weapons, but expensive. A roadblock built into the contract would be cheaper.

One wonders why the drafters of venture capital documents have not taken the simple step of forbidding any and all mergers absent a preferred class vote. In a negotiation over such a term, the anticipated objection would be that across-the-board vetoes in $V C$ create their own risk of opportunism - the $V C$ with a veto can hold up the deal so as to extract a disproportionately large consideration. But $E$ already is taking that risk with respect to all deals entailing a control transfer, and the more fully drafted term does not materially enhance its exposure.

\section{Summary}

Whether the glass of protection for preferred stockholders on the middle ground between draw down and redemption is half empty or half full remains a question. The venture capital arrangements discussed here derive many of their features from the practice of small business planning. Fitted to the startup firm's closely held status, these contracts are intensely relational as they simultaneously encourage entrepreneurs to maximize firm value while blocking opportunism against outside capital. They also reflect the fact that venture capitalists are not passive investors. Portfolio companies look to them for management assistance and service as reputational intermediaries 
with customers and suppliers. ${ }^{158}$ No diffusion of this contracting pattern to mature issuers and the public securities markets which concerned Graham and Dodd should be expected.

\section{CONCLUSION}

This Article's choice of incomplete contracts economics to describe venture capital contracts has normative implications. The economics suggest that ex post Coasian bargaining is not a vehicle well suited to optimal incentive alignment in corporations. Accordingly, when governance disputes erupt, a set of instructions needs to come from somewhere. The economics also suggest a zone of preference for shared control and process over advance specification. Accordingly, instructions will not always come in the form of advance contract specifications, and the legal system will be on call to provide thirdparty umpires.

On the matter of judicial umpiring, standard law and economics joins with the Delaware courts to counsel against intervention to protect relational victims on the theory that transacting parties should be encouraged to specify everything in advance in contracts. Alternatively, when the interests of common and senior holders conflict, law and economics again joins with Delaware in presuming in favor of the common. Here the theory is that short of an extreme distress situation, value is maximized when management decisions are aligned with the interests of the residual risk holder.

The incomplete contracts economics presented in this Article suggests a more circumspect approach. Where subject matter is noncontractible, a blanket presumption against ex post intervention on the ground of forced contract is incoherent. Furthermore, the control transfer model shows that efficient results and the interests of senior securityholders are aligned in a larger set of cases than previously supposed. When disputes between venture capitalists and entrepreneurs come to court, a rote presumption favoring the common stockholder is not defensible on efficiency grounds.

A legal case arises for better treatment of preferred. As presented here, the case asks for very little. No new fiduciary duty has to be implied. No new corporate tort need be invented. Conventional contract law merely needs to be applied in an evenhanded way. So doing would only enhance the reviewing court's reputation for responsiveness to business interests.

158. Sahlman, supra note 7 , at 508 . For a formal of the interactive relationship of venture capitalists and entrepreneurs at the draw down stage, see Rafael Repullo \& Javier Suarez, Venture Capital Finance: A Security Design Approach (SSRN Elec. Paper Coll. No. 145134, 1999), at http://papers.ssrn.com/abstract=145134. 